\title{
Drivers of the tropospheric ozone budget throughout the 21st century under the medium-high climate scenario RCP 6.0
}

\author{
L. E. Revell ${ }^{1,2}$, F. Tummon ${ }^{1}$, A. Stenke ${ }^{1}$, T. Sukhodolov ${ }^{1,3}$, A. Coulon ${ }^{1}$, E. Rozanov $^{1,3}$, H. Garny ${ }^{4}$, V. Grewe ${ }^{4}$, and \\ T. Peter ${ }^{1}$ \\ ${ }^{1}$ Institute for Atmospheric and Climate Science, ETH Zurich, Zurich, Switzerland \\ ${ }^{2}$ Bodeker Scientific, Christchurch, New Zealand \\ ${ }^{3}$ Physical-Meteorological Observatory/World Radiation Center, Davos, Switzerland \\ ${ }^{4}$ DLR, Institut für Physik der Atmosphäre, Oberpfaffenhofen, Germany \\ Correspondence to: L. E. Revell (laura.revell@env.ethz.ch)
}

Received: 18 September 2014 - Published in Atmos. Chem. Phys. Discuss.: 7 January 2015

Revised: 29 April 2015 - Accepted: 6 May 2015 - Published: 27 May 2015

\begin{abstract}
Because tropospheric ozone is both a greenhouse gas and harmful air pollutant, it is important to understand how anthropogenic activities may influence its abundance and distribution through the 21 st century. Here, we present model simulations performed with the chemistry-climate model SOCOL, in which spatially disaggregated chemistry and transport tracers have been implemented in order to better understand the distribution and projected changes in tropospheric ozone. We examine the influences of ozone precursor emissions (nitrogen oxides $\left(\mathrm{NO}_{x}\right)$, carbon monoxide (CO) and volatile organic compounds (VOCs)), climate change (including methane effects) and stratospheric ozone recovery on the tropospheric ozone budget, in a simulation following the climate scenario Representative Concentration Pathway (RCP) 6.0 (a medium-high, and reasonably realistic climate scenario). Changes in ozone precursor emissions have the largest effect, leading to a global-mean increase in tropospheric ozone which maximizes in the early 21 st century at $23 \%$ compared to 1960 . The increase is most pronounced at northern midlatitudes, due to regional emission patterns: between 1990 and 2060, northern midlatitude tropospheric ozone remains at constantly large abundances: $31 \%$ larger than in 1960. Over this 70 -year period, attempts to reduce emissions in Europe and North America do not have an effect on zonally averaged northern midlatitude ozone because of increasing emissions from Asia, together with the long lifetime of ozone in the troposphere. A simulation with fixed anthropogenic ozone precursor emissions of $\mathrm{NO}_{x}, \mathrm{CO}$ and non-methane VOCs at 1960 conditions
\end{abstract}

shows a $6 \%$ increase in global-mean tropospheric ozone by the end of the 21 st century, with an $11 \%$ increase at northern midlatitudes. This increase maximizes in the 2080s and is mostly caused by methane, which maximizes in the 2080s following RCP 6.0, and plays an important role in controlling ozone directly, and indirectly through its influence on other VOCs and CO. Enhanced flux of ozone from the stratosphere to the troposphere as well as climate change-induced enhancements in lightning $\mathrm{NO}_{x}$ emissions also increase the tropospheric ozone burden, although their impacts are relatively small. Overall, the results show that under this climate scenario, ozone in the future is governed largely by changes in methane and $\mathrm{NO}_{x}$; methane induces an increase in tropospheric ozone that is approximately one-third of that caused by $\mathrm{NO}_{x}$. Climate impacts on ozone through changes in tropospheric temperature, humidity and lightning $\mathrm{NO}_{x}$ remain secondary compared with emission strategies relating to anthropogenic emissions of $\mathrm{NO}_{x}$, such as fossil fuel burning. Therefore, emission policies globally have a critical role to play in determining tropospheric ozone evolution through the 21 st century.

\section{Introduction}

Ozone is a key trace gas in the atmosphere, with approximately $90 \%$ residing in the stratosphere and $10 \%$ in the troposphere. While stratospheric ozone is essential for shielding life on Earth from harmful ultraviolet (UV-B) radia- 
tion, tropospheric ozone has harmful effects because it is an air pollutant, with adverse effects on crop yields (and therefore food security), visibility (affecting, for example, all forms of traffic) and human health (West et al., 2007). Indeed, a recent study by Silva et al. (2013) found that anthropogenic ozone contributes towards 470000 respiratory deaths globally each year. Simultaneously, tropospheric ozone is a greenhouse gas that has contributed significantly to climate change; it has the third-highest pre-industrial to present-day radiative forcing after carbon dioxide $\left(\mathrm{CO}_{2}\right)$ and methane $\left(\mathrm{CH}_{4}\right)$ (Myhre et al., 2013; Stevenson et al., 2013). In addition to its roles in air pollution and climate change, tropospheric ozone is important in determining the oxidation capacity of the troposphere; the hydroxyl $(\mathrm{OH})$ radical is principally produced from ozone, and controls the lifetime of many atmospheric species such as $\mathrm{CH}_{4}, \mathrm{CO}$ and NMVOCs (non-methane volatile organic compounds), including some halocarbons (Thompson, 1992).

Ozone exists in the troposphere as a result of in situ chemical production and transport from the stratosphere. Approximately $90 \%$ is produced via chemical reactions between nitrogen oxides $\left(\mathrm{NO}_{x}=\mathrm{NO}+\mathrm{NO}_{2}\right)$, hydrocarbons and carbon monoxide (CO) during daylight hours (Denman et al., 2007); therefore air pollution policy can be expected to play a significant role in the evolution of tropospheric ozone through the 21st century and beyond. Depending on the sensitivity of ozone budget reactions to humidity and temperature, the distribution and abundance of tropospheric ozone may also be affected by climate change and changes in transport and convection through the 21st century. Ozone can also be transported, either from the stratosphere (stratospheretroposphere exchange, abbreviated to STE), or within the troposphere on long-range scales. Long-range ozone transport within the troposphere is modulated by decadal climate variability (Lin et al., 2014). Transport of ozone from the stratosphere is expected to increase through the 21 st century as: (1) stratospheric ozone abundances will increase, due to the phase-out of ozone-depleting halogenated substances under the Montreal Protocol, and due to stratospheric cooling slowing the ozone destruction cycles (Bekki et al., 2011); (2) stratosphere-to-troposphere transport of air will accelerate due to a strengthening of the Brewer-Dobson circulation as projected by climate models, resulting from enhanced tropospheric warming and convection, and subsequent wave activity (Butchart et al., 2010; Kawase et al., 2011). Both effects will lead to enhanced down-welling of ozone at midand polar latitudes. Stratospheric ozone recovery may further affect the evolution of tropospheric ozone through decreased solar actinic flux to the troposphere, which slows photolysis rates in the troposphere (Zhang et al., 2014).

In recent years as computational cost has declined, models which couple chemistry and climate (chemistry-climate models, or CCMs) have become increasingly complex, with many now including detailed tropospheric chemistry and other tropospheric processes. Morgenstern et al. (2013) used the UM-UKCA CCM to look at how climate change, stratospheric ozone recovery and methane affect ozone, although they did not consider future changes in non-methane ozone precursors. They found that climate change and stratospheric ozone recovery have approximately equal and opposite effects on surface ozone by 2050, resulting in an increase in tropospheric ozone driven by methane. Doherty et al. (2013) also investigated climate change-related effects on tropospheric ozone with an ensemble of three CCMs, and found that increased temperature and water vapour influenced surface ozone more strongly than climate change-induced enhancements in STE. Furthermore, several studies examining tropospheric ozone budgets and changes over time from the ACCMIP (Atmospheric Chemistry and Climate Model Intercomparison Project) ensemble of models have been published recently (e.g. Bowman et al., 2013; Stevenson et al., 2013; Young et al. 2013). The ensemble mean of results obtained from ACCMIP provides a useful point of reference for the results obtained in this study, and as such we refer to ACCMIP results later on.

To gain a clear insight into projected tropospheric ozone changes through the 21 st century, we have implemented a suite of chemistry and transport tracers into the SOCOL (Solar Climate Ozone Links) CCM, and used them to disentangle the various factors influencing the ozone budget in the free troposphere. Here we compare projected ozone changes in a future reference simulation, which assumes emissions of $\mathrm{NO}_{x}, \mathrm{CO}, \mathrm{CH}_{4}$ and NMVOCs according to Representative Concentration Pathway (RCP) 6.0, with those in simulations with ozone precursor emissions fixed at 1960 levels. Climate change and stratospheric ozone recovery are fully simulated in both scenarios, and the chemistry and transport tracers allow us to analyse their effects, for example by quantifying STE fluxes and tracking reaction rates for key ozone budget reactions.

\section{Computational methods}

\subsection{The SOCOL chemistry-climate model}

In order to understand the influences of ozone precursor emissions and climate change on the free tropospheric ozone budget (we focus mostly on the $500 \mathrm{hPa}$ level), simulations were performed with the SOCOL v.3 CCM. Its forerunner, SOCOL v.2, was extensively evaluated in the SPARC CCMVal-2 activity (SPARC CCMVal, 2010) in two variants; SOCOL operated by the ETH-Zurich group and NIWASOCOL operated by NIWA (National Institute of Water and Atmospheric Research, New Zealand). Both compared reasonably with other CCMs, obtaining performance grades in the midrange. Since then SOCOL has undergone some significant improvements from version 2 to 3 (notably, the core general circulation model has been updated, and the transport of chemical trace species is calculated with the advec- 
tion scheme of Lin and Rood (1996), rather than the hybrid scheme of Zubov et al. (1999), which was used in SOCOL v.2). As a result, SOCOL v.3 shows more realistic distributions of chemical trace species compared with its predecessors (both in the mean state and also with respect to annual and interannual variability), and slower tropical upwelling in the lower stratosphere; these changes, along with their effect on model performance, have been documented in detail by Stenke et al. (2013).

SOCOL v.3 consists of the MEZON chemistry transport model (Egorova et al., 2003) and MA-ECHAM5, the middle atmosphere version of the ECHAM general circulation model (Roeckner et al., 2003), with 39 vertical levels between Earth's surface and $0.01 \mathrm{hPa}(\sim 80 \mathrm{~km})$. For the present study, SOCOL was run with T42 horizontal resolution, which corresponds approximately to $2.8^{\circ} \times 2.8^{\circ}$. Dynamical processes in SOCOL are calculated every $15 \mathrm{~min}$ within the model, while radiative and chemical calculations are performed every 2 hours.

Chemical constituents are advected by a flux-form semiLagrangian scheme (Lin and Rood, 1996), and the chemical solver algorithm uses a Newton-Raphson iterative method taking into account 41 chemical species, 140 gas-phase reactions, 46 photolysis reactions, and 16 (stratospheric) heterogeneous reactions. Isoprene $\left(\mathrm{C}_{5} \mathrm{H}_{8}\right)$ oxidation is accounted for with the inclusion of the Mainz Isoprene Mechanism (MIM-1), which comprises 16 organic species (degradation products of isoprene) and a further 44 chemical reactions (Poeschl et al., 2000). Aside from isoprene and formaldehyde, we consider only the contribution to $\mathrm{CO}$ from other NMVOCs; that is, a certain fraction of the NMVOC emission is directly added to CO. For anthropogenic NMVOC emissions, the conversion factor to $\mathrm{CO}$ is 1.0 , for biomass burning it is 0.31 , and for biogenic NMVOC emissions it is 0.83; these conversion factors were derived from Ehhalt et al. (2001). Biogenic emissions are not interactive, but follow a climatology (described in Sect. 2.2).

Photolysis rates are calculated at every chemical time step using a look-up-table approach (Rozanov et al., 1999), including effects of the solar irradiance variability. The lookup tables provide photolysis rates as a function of $\mathrm{O}_{2}$ and $\mathrm{O}_{3}$ columns, meaning that the photolysis scheme sees interactive ozone. The impact of clouds on photolysis rates is accounted for by including a cloud modification factor, following Chang et al. (1987). Interactive lightning $\mathrm{NO}_{x}$ is calculated via a parametrization based on cloud top height (Price and Rind, 1992) with local scaling factors calculated from the Lightning Imaging Sensor (LIS) and Optical Transient Detector (OTD) satellite observations (Christian et al., 2003). Although the scaling approach is widely used to improve the representation of the global distribution of lightning, it carries some uncertainty as the future regions of lightning occurrence may differ from those currently observed (Murray et al., 2012). Furthermore, the scaling approach may pre- vent future changes in convective activity from modifying the magnitude of lightning $\mathrm{NO}_{x}$ production.

The treatment of stratospheric aerosols in SOCOL is described by Stenke et al. (2013). Tropospheric aerosols in SOCOL include sulfate, dust, sea salt, black carbon, organic carbon and methane sulfonate. For the simulations presented here, we used a tropospheric aerosol data set, as described by Anet et al. (2013). Tropospheric aerosols are used to calculate local heating rates and shortwave backscatter, however aerosol-cloud interactions and tropospheric heterogeneous chemistry are not considered.

Key reaction rates for the ozone budget were saved in every model grid cell, enabling chemistry to be analysed as a function of latitude, longitude, pressure and time. This approach was successfully used by Revell et al. (2012) to study stratospheric ozone chemistry. To better understand ozone transport, ozone tracers were implemented into SOCOL, based on the work of Grewe (2006) and Garny et al. (2011). Following this approach, the global ozone mixing ratio is disaggregated into 21 separate fields, according to in which of 21 predefined regions (defined by latitude and pressure) of the atmosphere the ozone originated; this approach is discussed further in Sect. 3.3.

To evaluate how realistically SOCOL simulates the distribution of tropospheric species, we compared ozone, $\mathrm{CO}$ and $\mathrm{NO}_{2}$ (three key components of the tropospheric ozone budget) with satellite measurements over the period 20052009. Level 3 ozone and CO profile data were taken from TES (Tropospheric Emission Spectrometer), a Fourier transform infrared spectrometer onboard NASA's Aura satellite (e.g. Ho et al., 2009; Richards et al., 2008). Tropospheric $\mathrm{NO}_{2}$ columns were compared with those measured by OMI (Ozone Monitoring Instrument) (Boersma et al., 2007).

\subsection{Emission scenarios}

SOCOL simulations were performed in support of the IGAC/SPARC Chemistry-Climate Model Initiative (CCMI; Eyring et al., 2013a), and therefore the boundary conditions used here adhere to the specifications of CCMI simulations, namely the REF-C2 and SEN-C2-fEmis simulations (hereafter fEmis, for brevity). These transient simulations are described in depth by Eyring et al. (2013a), but salient details are reproduced in Table 1 . The REF-C2 simulation (1960-2100) was developed as a future reference simulation, to understand how the atmosphere would evolve under "best guess" estimates of future greenhouse gas concentrations, ozone-depleting substances (ODSs), ozone precursor emissions and sea-surface temperatures (SSTs). REFC2 is based on RCP 6.0, a medium-high climate change scenario. Prescribed mixing ratios of greenhouse gases and long-lived chlorine, as well as emission fluxes of surface $\mathrm{NO}_{x}$, NMVOCs and $\mathrm{CO}$ for the REF-C2 simulation are shown in Fig. 1. For biogenic isoprene, formaldehyde and other NMVOC emissions we use a climatology for the year 
Table 1. Summary of boundary conditions used for the SOCOL CCM simulations.

\begin{tabular}{llll}
\hline & $\begin{array}{l}\text { REF-C2 } \\
(1960-2100)\end{array}$ & $\begin{array}{l}\text { fEmis } \\
(1960-2100)\end{array}$ & fCH $_{4}(1960-2100)$ \\
\hline $\begin{array}{l}\text { Greenhouse gases } \\
\left(\mathrm{CO}_{2}, \mathrm{~N}_{2} \mathrm{O}, \mathrm{CH}_{4}\right)\end{array}$ & $\begin{array}{l}\text { Observations until 2005 then RCP 6.0 } \\
\text { (Masui et al., 2011). }\end{array}$ & Same as REF-C2. & $\begin{array}{l}\mathrm{CO}_{2} \text { and } \mathrm{N}_{2} \mathrm{O} \text { same as REF- } \\
\mathrm{C}^{2} \mathrm{CH}_{4} \text { fixed at 1960 levels. }\end{array}$ \\
\hline $\begin{array}{l}\text { Ozone precursor } \\
\text { emissions }\end{array}$ & $\begin{array}{l}\text { Historical emissions until 2000 } \\
\text { (Lamarque et al., 2010), then RCP 6.0. }\end{array}$ & Fixed at 1960 levels. & Fixed at 1960 levels. \\
\hline SSTs & $\begin{array}{l}\text { Observations until 2005 (Rayner et al., } \\
\text { 2003), then RCP 6.0 (Meehl et al., }\end{array}$ & & Same as REF-C2. \\
& 2013). & & \\
\hline ODSs & $\begin{array}{l}\text { The A1 scenario from WMO (2011), } \\
\text { which includes observations until 2009. }\end{array}$ & Same as REF-C2. & Same as REF-C2. \\
\hline
\end{tabular}

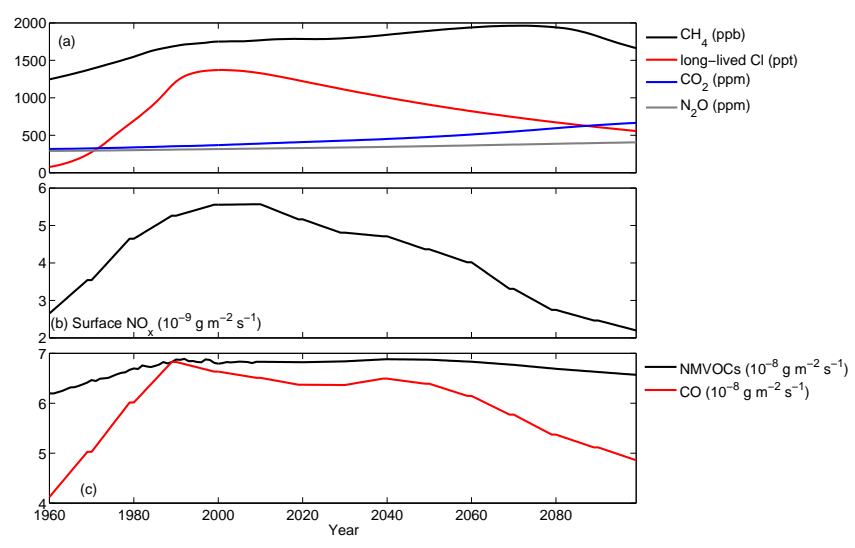

Figure 1. Boundary conditions used in the REF-C2 simulation (global-mean concentrations/emission fluxes). (a) $\mathrm{CO}_{2}, \mathrm{CH}_{4}, \mathrm{~N}_{2} \mathrm{O}$ mixing ratios following RCP 6.0, and long-lived chlorine mixing ratios following the WMO A1 scenario for ODSs. (b) Surface $\mathrm{NO}_{x}$ emission fluxes, following RCP 6.0. (c) Surface CO and NMVOC emission fluxes, following RCP 6.0.

2000 (based on a MEGAN (Model of Emissions of Gases and Aerosols from Nature; Guenther et al., 2006) run), while the biomass burning emissions follow those described by Lamarque et al. (2010) until 2000, and RCP 6.0 thereafter. Similarly, anthropogenic emissions of formaldehyde and other anthropogenic NMVOCs follow Lamarque et al. (2010) until 2000, then RCP 6.0.

The fEmis "fixed emissions" simulation (1960-2100) is identical to REF-C2, except that non-methane ozone precursor emissions are held constant at 1960 levels. For the present study, this simulation allowed us to explore the question of how global tropospheric ozone would evolve if air pollution remained at continuously low (1960) levels throughout the 21 st century. Because methane is also an air pollutant but not fixed at 1960 levels in the fEmis simulation (as we are interested in its climate impact), we ran a $\mathrm{fCH}_{4}$ "fixed methane" simulation for 1960-2100. The $\mathrm{fCH}_{4}$ simulation used identi- cal boundary conditions to the fEmis simulation, except that methane concentrations were held constant at 1960 levels (thus impacting both chemistry and radiation directly).

Simulations were started in 1950 to allow 10 years for the model to reach a steady state; this spin-up period was subsequently discarded and not used in our analyses.

\section{Results and discussion}

\subsection{Evaluation of model performance}

Model simulated ozone, $\mathrm{CO}$ and $\mathrm{NO}_{2}$ fields from the SOCOL REF-C2 simulation were compared to satellite observations over the period 2005-2009 (Fig. 2). Ozone and CO profiles were taken from TES and $\mathrm{NO}_{2}$ columns from OMI. The WMO-defined tropopause was used to calculate SOCOL $\mathrm{NO}_{2}$ columns. SOCOL data were not processed with satellite operators (such as averaging kernels). While this results in a less meaningful comparison, it has been shown that only minor differences result from the application of satellite operators (Huijnen et al., 2010). We chose the period 20052009 over which to compare data as it is representative of the present day and because of good data availability for this period. Relative to TES, SOCOL has a large positive ozone bias at $500 \mathrm{hPa}$ of up to $30 \mathrm{ppb}$ in the Northern Hemisphere and tropics, and a smaller negative bias $(\sim 5-10 \mathrm{ppb})$ in the Southern Hemisphere (Fig. 2a-c). Surface ozone in SOCOL is biased on a similar order of magnitude in the Northern Hemisphere compared with the mid-troposphere, with ozone over Europe, the US and Asia up to 20 ppb higher in 2000 compared with the ACCMIP ensemble mean (Young et al., 2013).

One possibility for the large Northern Hemisphere bias might be a too-weak removal of $\mathrm{NO}_{x}$ from the troposphere, which is described by the $\mathrm{HNO}_{3}$ washout process. In the model setup for the present study, a constant removal value was applied to the $\mathrm{HNO}_{3}$ gas phase at each time step $(2.5 \%$ of gas-phase $\mathrm{HNO}_{3}$ was removed everywhere up to $160 \mathrm{hPa}$, 

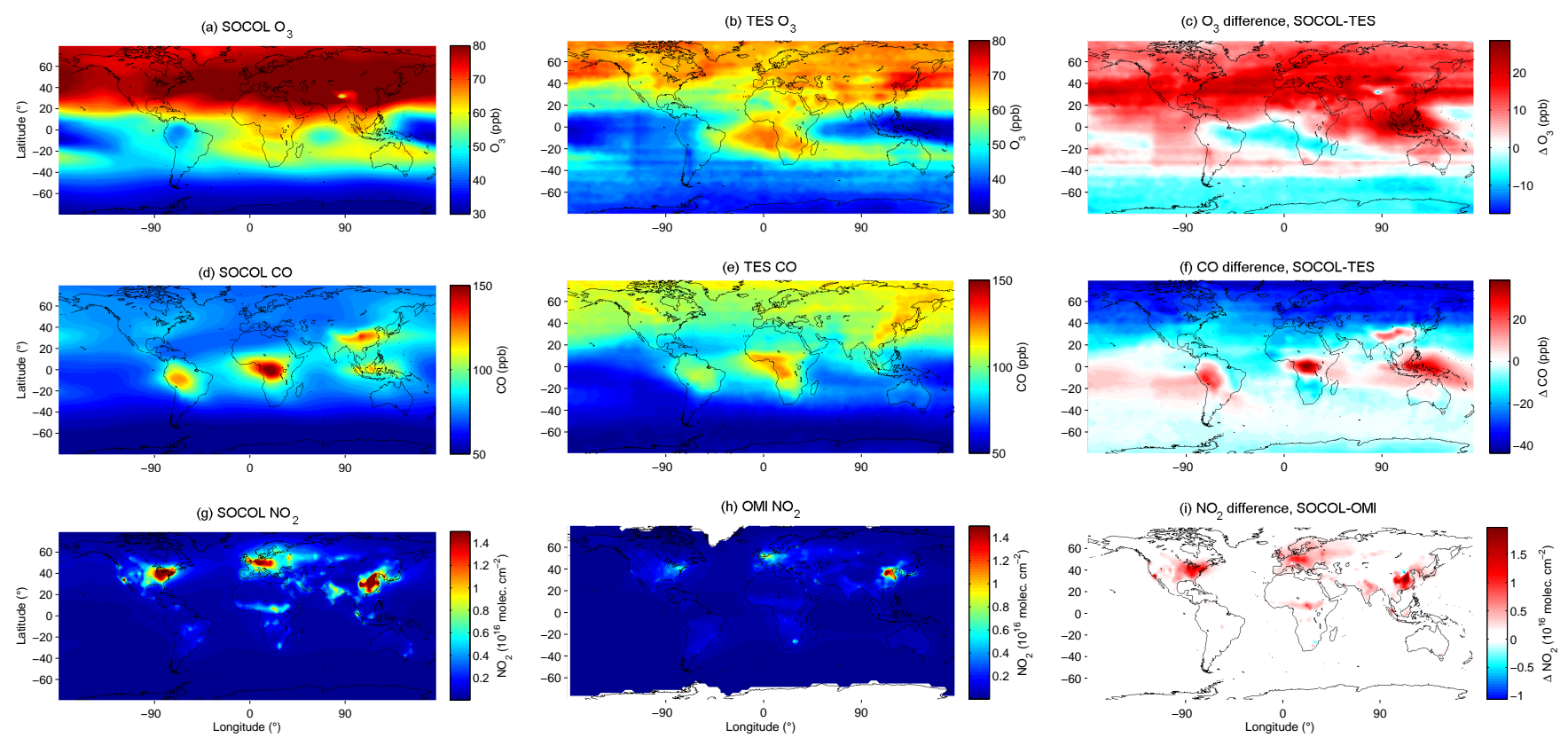

Figure 2. Comparisons of SOCOL model results (from the REF-C2 simulation) with observations, averaged over 2005-2009, for: (a) SOCOL ozone, $500 \mathrm{hPa}$; (b) TES ozone, $464 \mathrm{hPa}$; (c) ozone difference (panel (a) minus (b)); (d) SOCOL CO, $500 \mathrm{hPa}$; (e) TES CO, $464 \mathrm{hPa}$; (f) CO difference (panel d minus e); (g) SOCOL tropospheric column $\mathrm{NO}_{2}$; (h) OMI tropospheric column $\mathrm{NO}_{2}$; (i) $\mathrm{NO}_{2}$ difference (panel $\mathbf{g}$ minus h).

independent of clouds or rainfall). Because $\mathrm{HNO}_{3}$ can lead to ozone production when it is photolyzed to form $\mathrm{NO}_{2}$, recently obtained results suggest that a more realistic removal process for $\mathrm{HNO}_{3}$ (based on in-cloud and below-cloud precipitation, and aerosol interaction; Chang, 1984; Seinfeld and Pandis, 2006) indeed reduces SOCOL's overly large ozone burden in the Northern Hemisphere. However, the effect is not systematic, and this is not pursued in the present study.

We note also that SOCOL is not alone among the current generation of models in overestimating northern midlatitude ozone. Small systematic high biases in the Northern Hemisphere and low biases in the Southern Hemisphere were also observed in the ACCMIP models (Bowman et al., 2013; Young et al., 2013). ACCMIP included a range of models, from coupled CCMs with comprehensive tropospheric and stratospheric chemistry, to chemistry transport models (CTMs) which do not calculate meteorology online, and CCMs with very simple tropospheric chemistry (Lamarque et al., 2013). Because the models used the same emissions (as each other, and as in the present study), it was concluded that "the prevalence of this bias could suggest they [the emissions] are deficient in some way, in either their amount or distribution, or both" (Young et al., 2013). It is not clear whether SOCOL's high ozone bias is a source issue (that is, emissions), a sink issue $\left(\mathrm{HNO}_{3}\right.$ washout), or a combination of the two, and this requires further investigation. However, similar to the ACCMIP models, SOCOL correlates spatially very well with observations, despite bi- ases in absolute ozone values; ozone concentrations are elevated in the Northern Hemisphere and over Africa compared with the Southern Hemisphere, and low ozone concentrations are seen over the tropical Pacific Ocean (discussed further in Sect. 3.2).

SOCOL simulates higher $\mathrm{CO}$ over regions where biomass burning is prevalent, namely South America, Africa and Indonesia, than observed by TES (Fig. 2d-f). Southern Hemisphere CO in SOCOL is in good agreement with TES; however, in the Northern Hemisphere, $\mathrm{CO}$ is biased low by 20 $40 \mathrm{ppb}$. The low Northern Hemisphere $\mathrm{CO}$ bias is linked with the high ozone bias in the same region, as ozone is the primary source of the $\mathrm{OH}$ radical, which in turn oxidizes CO. Similar biases in $\mathrm{CO}$ were observed in the ACCMIP models; at $500 \mathrm{hPa}$, the multi-model mean is biased high compared with satellite observations over South America, Africa and Indonesia, and thought to be linked to biomass burning emissions (Naik et al., 2013). Furthermore, as seen in SOCOL, the multi-model mean is in good agreement with observations in the Southern Hemisphere. The $\mathrm{OH}$ abundance is also in agreement with the multimodel mean of the ACCMIP models; in the year 2000, the global tropospheric air mass-weighted $\mathrm{OH}$ concentration is $11.5 \times 10^{5}$ molecules $\mathrm{cm}^{-3}$, compared with the multi-model mean of $11.7 \pm 1.0$ molecules $\mathrm{cm}^{-3}$ in the ACCMIP models (Voulgarakis et al., 2013).

SOCOL reproduces the elevated tropospheric $\mathrm{NO}_{2}$ columns observed by OMI over North America, Europe and 
Asia, but overestimates their magnitude (Fig. 2g-i); this is linked in part to $\mathrm{HNO}_{3}$ washout from the troposphere (as described above), and also leads to the general high ozone bias in SOCOL throughout the Northern Hemisphere, which is likely related to emissions. We note that potential discrepancies in emissions are a major source of uncertainty in our analyses. Indeed, Parrish et al. (2014) identify emissions as an issue in need of attention, given that CCMs consistently overestimate tropospheric ozone mixing ratios, and underestimate the magnitude of tropospheric ozone changes over the past 50-60 years.

As discussed in Sect. 2.1, tropospheric aerosols are considered in SOCOL's radiation scheme but not in the photolysis or heterogeneous chemistry schemes, which may be a further reason for the tropospheric ozone biases. Dentener and Crutzen (1993) showed that $\mathrm{N}_{2} \mathrm{O}_{5}$ hydrolysis on tropospheric aerosols reduces the tropospheric ozone burden by $10-25 \%$, although the reaction probabilities they used were likely too large. Recent sensitivity simulations with the SOCOL model show that tropospheric ozone is reduced by a maximum of $10 \%$ when $\mathrm{N}_{2} \mathrm{O}_{5}$ hydrolysis is included in the model (following the parametrization of Evans and Jacob, 2005), although some regions show a slight increase in tropospheric ozone. Improving the treatment of tropospheric aerosols in SOCOL is the subject of ongoing research, and is not further addressed here.

Although SOCOL is subject to several biases in terms of absolute species concentrations, it captures the latitudinal and longitudinal distributions of ozone, $\mathrm{CO}$ and $\mathrm{NO}_{2}$ convincingly. Furthermore, given that the changes in ozone, $\mathrm{NO}_{x}$, NMVOCs and CO over the period 2010-2100 are of the same order of magnitude as past changes between 19602010 (shown later in Fig. 5), we do not expect non-linear feedbacks caused by the processes contributing to the biases to severely compromise our results for the future. We now proceed to discuss the distribution of ozone in the 1960s, and the model-simulated changes until 2100.

\subsection{Tropospheric ozone chemistry}

Although tropospheric ozone chemistry is comprehensive and complex, we outline below some fundamental reaction cycles, as they are useful in discussing SOCOL's spatial ozone distribution later in this section. In the troposphere, ozone is produced via reaction cycles that begin with oxidation of a NMVOC or $\mathrm{CO}$, as shown below:

$$
\begin{aligned}
& \mathrm{CO}+\mathrm{OH} \rightarrow \mathrm{CO}_{2}+\mathrm{H} \\
& \mathrm{H}+\mathrm{O}_{2}+M \rightarrow \mathrm{HO}_{2}+M \\
& \mathrm{HO}_{2}+\mathrm{NO} \rightarrow \mathrm{NO}_{2}+\mathrm{OH} \\
& \mathrm{NO}_{2}+h v \rightarrow \mathrm{NO}+\mathrm{O} \\
& \frac{\mathrm{O}+\mathrm{O}_{2}+M \rightarrow \mathrm{O}_{3}+M}{\mathrm{CO}+2 \mathrm{O}_{2} \rightarrow \mathrm{CO}_{2}+\mathrm{O}_{3} .}
\end{aligned}
$$

The reaction $\mathrm{HO}_{2}+\mathrm{NO}$ is the rate-limiting step in ozone production and determines that the net effect of this cycle is ozone production with a gross production rate Reaction (R1). Other ozone producing cycles follow the oxidation of VOCs, such as methane, formaldehyde, or isoprene and its degradation products, leading to

$\mathrm{RO}_{2}+\mathrm{NO} \rightarrow \mathrm{NO}_{2}+\mathrm{RO}$,

where $\mathrm{R}$ represents the organic chain of the molecules $\mathrm{RO}_{2}$ and RO.

In contrast, when air is $\mathrm{NO}_{x}$-poor, rather than reacting with $\mathrm{NO}$, as in the ozone production cycle (R1) above, the generated peroxy radicals $\mathrm{HO}_{2}$ (and generally $\mathrm{RO}_{2}$ ), will instead react with ozone, as in the cycles below, which are catalytic in $\mathrm{HO}_{x}$, with ozone net loss rates Reactions (R3) and (R4):

$$
\begin{aligned}
& \mathrm{CO}+\mathrm{OH} \rightarrow \mathrm{CO}_{2}+\mathrm{H} \\
& \mathrm{H}+\mathrm{O}_{2}+M \rightarrow \mathrm{HO}_{2}+M \\
& \frac{\mathrm{HO}_{2}+\mathrm{O}_{3} \rightarrow \mathrm{OH}+2 \mathrm{O}_{2}}{\mathrm{CO}+\mathrm{O}_{3} \rightarrow \mathrm{CO}_{2}+\mathrm{O}_{2}} \\
& \mathrm{OH}+\mathrm{O}_{3} \rightarrow \mathrm{HO}_{2}+\mathrm{O}_{2} \\
& \frac{\mathrm{HO}_{2}+\mathrm{O}_{3} \rightarrow \mathrm{OH}+2 \mathrm{O}_{2}}{2 \mathrm{O}_{3} \rightarrow 3 \mathrm{O}_{2} .}
\end{aligned}
$$

In the tropics, where humidity and solar actinic fluxes are high, the following reaction mechanism (R5) can become the leading ozone loss reaction, even though it is not catalytic:

$$
\begin{aligned}
& \mathrm{O}_{3}+h v \rightarrow \mathrm{O}\left({ }^{1} \mathrm{D}\right)+\mathrm{O}_{2} \quad(\lambda<320 \mathrm{~nm}) \\
& \frac{\mathrm{O}\left({ }^{1} \mathrm{D}\right)+\mathrm{H}_{2} \mathrm{O} \rightarrow 2 \mathrm{OH}}{\mathrm{O}_{3}+\mathrm{H}_{2} \mathrm{O}+h v \rightarrow \mathrm{O}_{2}}+2 \mathrm{OH} .
\end{aligned}
$$

In extremely $\mathrm{NO}_{x}$-poor environments, ozone loss by Reaction (R5) can occur to such a large extent that minima in tropospheric ozone ensue, as in over the Amazon Basin and tropical Pacific Ocean in Fig. 3a. Minima in tropical Western Pacific ozone have been observed in a number of measurement campaigns (Kley et al., 1996; Singh et al., 1996; Tsutsumi et al., 2003; Rex et al., 2014). Furthermore, Rex et al. (2014) showed, using ozone and $\mathrm{OH}$ measurements in combination with the GEOS-Chem CTM, that very low tropospheric ozone and $\mathrm{OH}$ abundances exist in the tropical Western Pacific. Rex et al. (2014) explained that low OH abundances are concomitant with low ozone abundances in the tropical Western Pacific because ozone is the principal source of $\mathrm{OH}$, and ozone loss via Reaction (R5) is so pronounced in this region. They also noted that low $\mathrm{NO}_{x}$ abundances further reduce $\mathrm{OH}$ because production of $\mathrm{OH}$ via $\mathrm{HO}_{2}+\mathrm{NO} \rightarrow \mathrm{OH}+\mathrm{NO}_{2}$ becomes very slow (Gao et al., 2014). Results obtained from SOCOL largely support this 
hypothesis, except that the $\mathrm{OH}$ and ozone minima are located in slightly different places (over Indonesia and over the Western Pacific Ocean, respectively, which was also found by Voulgarakis et al., 2013). We suggest, therefore, that relatively high abundances of $\mathrm{CO}$ and VOCs from biomass burning are important for $\mathrm{OH}$ depletion, in combination with low $\mathrm{NO}_{x}$ abundances. The combination of high $\mathrm{CO}+\mathrm{VOCs}$ and low $\mathrm{NO}_{x}$ drives ozone loss via Reaction (R3), and suppresses ozone production via Reaction (R1). In addition, ozone loss by Reaction (R5) is fast because of high humidity and solar actinic fluxes in this region. Because ozone and $\mathrm{NO}_{x}$ abundances are so low over Indonesia, the $\mathrm{HO}_{x}$ partitioning from $\mathrm{HO}_{2}$ into $\mathrm{OH}$ (via reaction of $\mathrm{HO}_{2}$ with ozone in Reaction (R3), and via reaction of $\mathrm{HO}_{2}$ with $\mathrm{NO}$ in Reaction R1) becomes very slow, resulting in low modelled $\mathrm{OH}$ abundances (Fig. 3b).

Figure $3 \mathrm{c}$ and $\mathrm{d}$ show the ratios of ozone production : loss, defined here as (R1 + R2) / (R3 + R4 + R5) and $\mathrm{NO}_{x}$ : NMVOCs $+\mathrm{CO}$, respectively. We consider $\mathrm{CO}$ and NMVOCs together as they both undergo oxidation to initiate ozone production and destruction cycles. Here, NMVOCs are $\mathrm{C} 2-\mathrm{C} 5$ species that are related to isoprene, belonging to the reduced mechanism (MIM-1) outlined by Poeschl et al. (2000). One limitation of SOCOL is that the set of NMVOCs included is very small - namely formaldehyde, isoprene and the 15 other isoprene degradation products included in the MIM-1 isoprene oxidation mechanism. However, this subset of NMVOCs makes the mechanism detailed enough to accurately reproduce the diurnal cycle of important intermediate species like carbonyls, hydroperoxides and alkyl and peroxyl acyl nitrates, thus enabling the most relevant chemical processes for the tropospheric ozone budget to be represented (Poeschl et al., 2000). As shown in Fig. 3c and d, regions with high $\mathrm{NO}_{x}$ and low NMVOC $+\mathrm{CO}$ concentrations generally have high ozone production rates relative to ozone loss.

\subsection{Projections for the 21st century}

Given the projected changes in ozone precursor emissions, greenhouse gases and stratospheric ozone in the REF-C2 and fEmis simulations, how is tropospheric ozone projected to evolve through the 21 st century? Further, are the projected changes dominated by changes in precursor emissions or by changes in climate? We focus our tropospheric analysis in the mid-troposphere, at $500 \mathrm{hPa}$. At this pressure the regional to hemispheric background ozone concentration is established, and the signal is broadly consistent with the surface, as seen when comparing Fig. $3 \mathrm{a}$ (ozone at $500 \mathrm{hPa}$ ) with Fig. 4 (surface ozone). Furthermore, as shown later in Fig. 7, most of the tropospheric ozone transport between low, middle and high latitudes happens in the mid-troposphere. $500 \mathrm{hPa}$ is also high enough in the atmosphere to be able to compare model output with satellite observations, as here the satellite instruments have better sensitivity compared with closer to the surface (Fig. 2).

Figure 5 shows the model-simulated free tropospheric concentrations of $\mathrm{NO}_{x}$ and NMVOCs $+\mathrm{CO}$, as well as tropospheric and stratospheric ozone for the tropics and northern and southern midlatitudes. For the stratosphere, Fig. 5d shows that extratropical stratospheric column ozone is projected to increase through the 21st century in both the REF$\mathrm{C} 2$ and fEmis simulations, owing to the phase-out of halocarbon gases under the Montreal Protocol on Substances that Deplete the Ozone Layer. Because of $\mathrm{CO}_{2}$-induced cooling of the stratosphere (Bekki et al., 2011) and the increased rate of tropical upwelling (Avallone and Prather, 1996), the Northern and Southern Hemisphere stratospheric ozone columns increase to values slightly higher than those in 1980 by the end of the 21 st century. Projected accelerated tropical upwelling is also expected to lead to slight decreases in tropical stratospheric ozone through the 21 st century, as seen here.

In the troposphere, the REF-C2 simulation shows that concentrations of $\mathrm{NO}_{x}$, NMVOCs and CO increase dramatically through the late 20th century (Fig. 5a-b), but eventually start to decrease towards the end of the 21st century. Although anthropogenic NMVOC and CO emissions are fixed at 1960 levels in the fEmis simulation, an increase of $\mathrm{CO}$ still occurs as it is an oxidation product of $\mathrm{CH}_{4}$, and $\mathrm{CH}_{4}$ itself is not fixed at 1960 levels, but rather follows RCP 6.0 (Masui et al., 2011).

Global-mean tropospheric ozone increases substantially through the 20th century in the REF-C2 simulation, by $23 \%$ until the 2020 s, stays at these high values for about 40 years, and then decreases in the late 21 st century (leading to an overall global-mean increase of $8 \%$ between 1960 and 2100). The global-mean tropospheric ozone burden decreases by $1 \%$ between $2000-2030$, and $10 \%$ between 2000-2100. These decreases are similar to the ensemble mean of the ACCMIP models which performed the RCP 6.0 simulation, of $1 \%$ and $9 \%$ between 2000-2030 and 2000-2100, respectively (Young et al., 2013).

One seemingly inconsistent feature of Fig. 5 is that at northern midlatitudes, $\mathrm{NO}_{x}$ and $\mathrm{NMVOC}+\mathrm{CO}$ concentrations decrease in the early 21 st century, yet ozone concentrations in the REF-C2 simulation remain constant. To explain this feature, one must examine the spatial changes in ozone and its precursor emissions. Figure $6 \mathrm{a}-\mathrm{b}$ show that $\mathrm{NO}_{x}$ and NMVOC $+\mathrm{CO}$ both decrease in the Northern Hemisphere over Europe (and North America, in the case of $\mathrm{NO}_{x}$ ). Therefore, ozone decreases by up to $4 \%$ between the 2000 s and 2020s over Europe (Fig. 6c). However, the decrease in $\mathrm{NO}_{x}$ of approximately $20 \%$ over Europe and North America is compensated for by up to a $40 \%$ increase in $\mathrm{NO}_{x}$ over Asia. In turn, this incurs an increase in ozone of up to $6 \%$ in the same region, and, because of ozone's long lifetime in the troposphere, the increase extends as far as the west coast of North America. The decreases in ozone and its precursor 

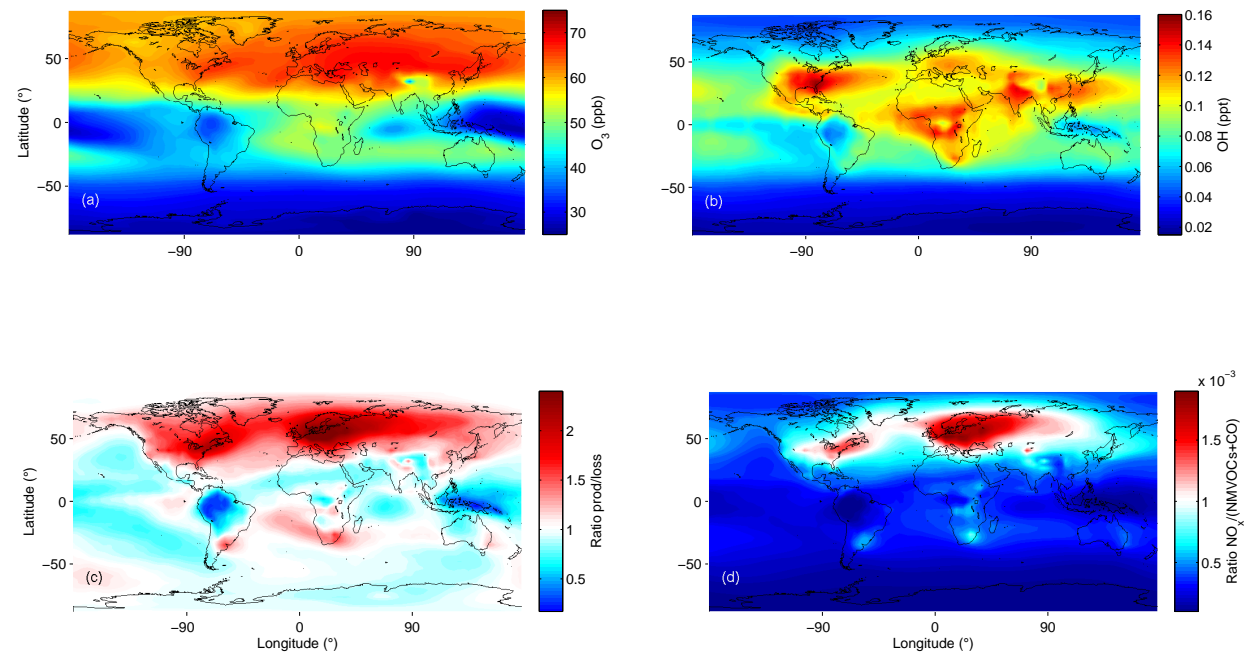

Figure 3. Results from the REF-C2 simulation, 1960-1969 average, 500 hPa. (a) Ozone; (b) OH; (c) ratio of ozone production over loss; (d) ratio of $\mathrm{NO}_{x}: \mathrm{NMVOCs}+\mathrm{CO}$.

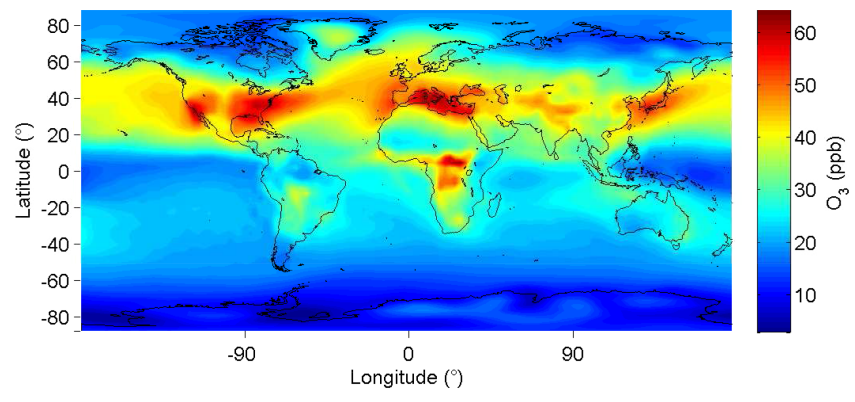

Figure 4. As for Fig. 3a, but for the surface instead of $500 \mathrm{hPa}$.

emissions over Europe and North America and the increases over Asia are statistically significant at the $95 \%$ level of confidence.

As shown in Fig. 6, changing regional emission patterns explain the substantial effect on northern midlatitude tropospheric ozone (Fig. 5c): by 1990, tropospheric ozone is $31 \%$ higher than in 1960, and such high abundances are sustained until 2060. Attempts by Europe and North America to reduce emissions are offset by increases from Asia. It is well known that ozone formed from precursor emissions in Asia can be transported across the Pacific Ocean to the US, and this has previously been shown by, amongst others, Auvray et al. (2007), Derwent et al. (2008) and Zhang et al. (2010). Europe may also expect to be affected by increased emissions from other Northern Hemisphere sources in the early to mid21st century; Auvray and Bey (2005) showed that Asian and North American sources of ozone contribute $8 \%$ and $11 \%$ of the European annual ozone budget, respectively.

We further show decadal-mean ozone fluxes around the lower stratosphere and troposphere in Fig. $7-15$ of the 21 tracer regions are shown, with the remaining six regions located in the upper stratosphere above $30 \mathrm{hPa}$. Figure $7 \mathrm{a}$ quantifies ozone fluxes $\left(\mathrm{Tg} \mathrm{yr}^{-1}\right)$ around the boundary layer $(850-1000 \mathrm{hPa})$ and free troposphere $(100-850 \mathrm{hPa}$ between $30^{\circ} \mathrm{N}-30^{\circ} \mathrm{S}$ and $200-850 \mathrm{hPa}$ elsewhere), ascent of air from the tropics into the stratosphere, and downwelling from the stratosphere at extratropical latitudes, for the 1960s. Figure $7 \mathrm{~b}$ shows the same plot for the 2050s, with increases of more than $20 \%$ since the 1960s marked in red; this serves to highlight the increased export of ozone from tropical and northern midlatitude regions in the troposphere and boundary layer to surrounding regions (such as northern high latitudes), due to increased ozone production from precursor emissions in these regions between 1960-2050.

Decadal variability will also influence long-range transport of ozone within the troposphere through the 21st century. Under RCP 6.0, there is an increased tendency towards more El Niño conditions (consistent with the findings of e.g. Cai et al. (2014), although they examined RCP 8.5), which is linked with a strengthening of the flow of ozone-rich air from Europe and Asia across the Pacific Ocean towards Hawaii in Northern Hemisphere autumn (Lin et al., 2014). As El Niño conditions become increasingly prevalent, more eastward transport of ozone across the Pacific Ocean may be expected to occur.

\subsection{Ozone change with fixed precursor emissions}

As shown in Fig. 5b, holding CO and NMVOC emissions constant at 1960 levels does not equate to constant concentrations of those species in the troposphere through the 21st century, because methane is an important source of $\mathrm{CO}$ and an ozone precursor in its own right (e.g., Seinfeld and Pandis, 2006), and methane is not held constant in the fEmis simulation. Figure $5 \mathrm{c}$ shows that in the absence of $\mathrm{NO}_{x}$, the tropospheric ozone concentration maximizes in the 2080s in 

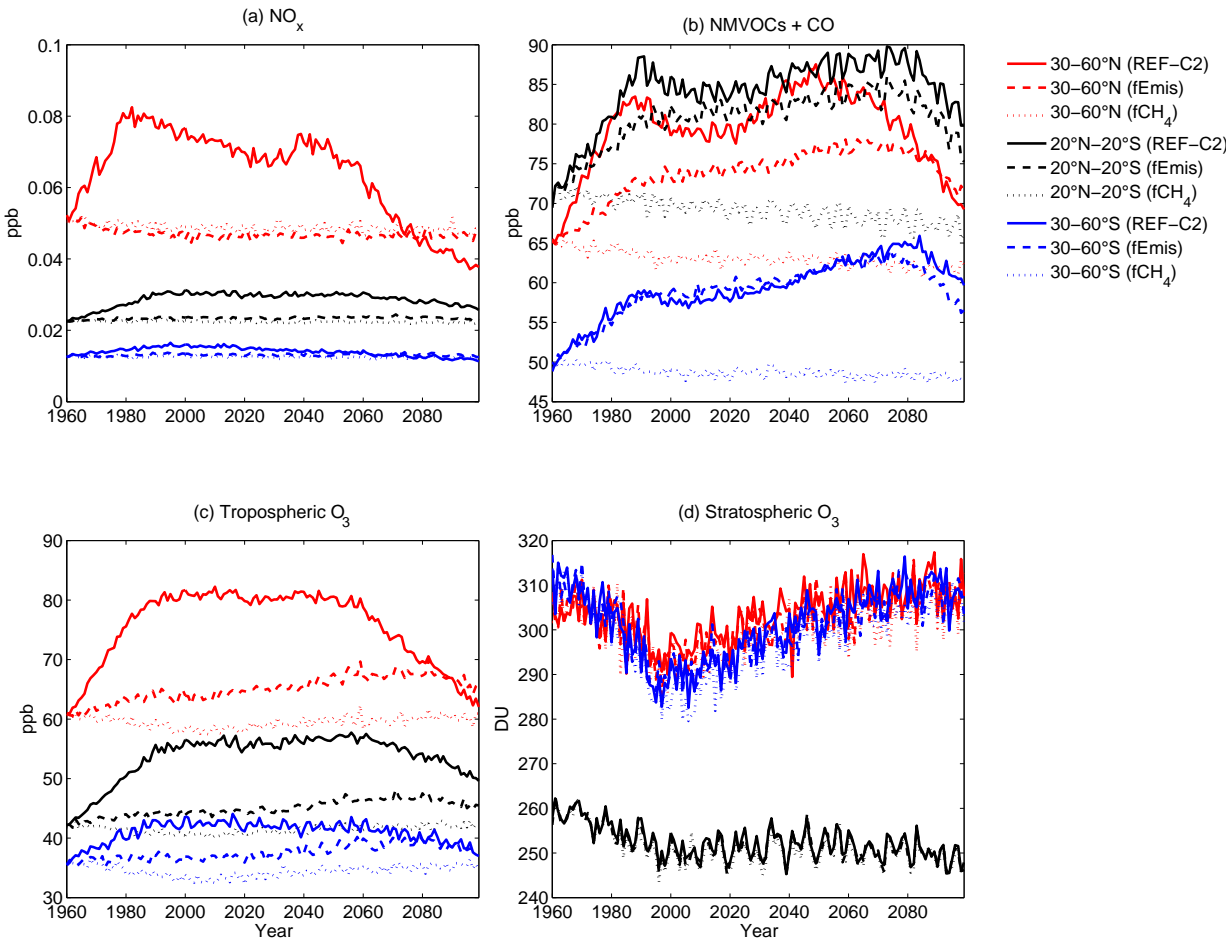

Figure 5. Time series of northern midlatitude $\left(30-60^{\circ} \mathrm{N}\right.$, red lines), tropical $\left(20^{\circ} \mathrm{N}-20^{\circ} \mathrm{S}\right.$, black lines) and southern midlatitude $\left(30-60^{\circ} \mathrm{S}\right.$, blue lines): (a) $\mathrm{NO}_{x}(500 \mathrm{hPa})$; (b) NMVOCs + CO $(500 \mathrm{hPa})$; (c) tropospheric ozone $(500 \mathrm{hPa})$; (d) stratospheric column ozone. Solid lines: for the REF-C2 simulation. Dashed lines: fEmis simulation. Dotted lines: $\mathrm{fCH}_{4}$ simulation.

the fEmis simulation, which is approximately when methane concentrations maximize following RCP 6.0 (Fig. 1a).

To understand the effect on tropospheric ozone abundances if all ozone precursors, including methane, were held constant at 1960 levels, we ran an fEmis simulation with fixed methane (referred to as the $\mathrm{fCH}_{4}$ simulation) for 1960 2100. Figure 5a shows that fixing methane does not significantly impact $\mathrm{NO}_{x}$ concentrations. This demonstrates that modelled $\mathrm{NO}_{x}$ is driven by chemistry, rather than climateinduced changes in meteorology. As noted in Sect. 2.1, the scaling approach used to calculate lightning $\mathrm{NO}_{x}$ may not modify the magnitude of future lightning $\mathrm{NO}_{x}$ production which might be expected to result from changes in convective activity.

Figure 5 b shows that compared with 1960 , NMVOC + CO concentrations in the $\mathrm{fCH}_{4}$ simulation are 5-10 ppb lower by the end of the 21 st century at northern midlatitudes and in the tropics, and decrease slightly at southern midlatitudes. In the 2080s, when methane concentrations maximize following RCP 6.0, NMVOC+CO concentrations in the $\mathrm{fCH} 4$ simulation are significantly lower than in the fEmis and REFC2 simulations: in the global average, $\mathrm{NMVOC}+\mathrm{CO}$ concentrations are $4 \%$ lower in the fEmis simulation compared with the REF-C2, and $22 \%$ lower in the $\mathrm{fCH}_{4}$ simulation compared with the REF-C2. This corroborates the finding of Wang and Prinn (1999), that controlling methane emissions is more effective in controlling $\mathrm{NMVOC}+\mathrm{CO}$ concentrations in the troposphere, than controlling $\mathrm{NMVOC}+\mathrm{CO}$ emissions themselves.

Figure $5 \mathrm{c}$ shows that tropospheric ozone concentrations in the 2080s of the $\mathrm{fCH}_{4}$ simulation are approximately the same as in the 1960s. In the global mean, ozone in the $\mathrm{fCH}_{4}$ simulation is $16 \%$ lower than in the REF-C2 simulation and $10 \%$ lower than in the fEmis simulation. Methane has been shown to be an important ozone precursor historically, with both Shindell et al. (2009) and Lang et al. (2012) finding it to be responsible for most of the tropospheric ozone increase from pre-industrial to present times. Studies that have modelled projected tropospheric ozone under the different RCPs find methane to be the largest factor defining differences between the projections, because the RCPs assume huge reductions in $\mathrm{NO}_{x}$ and NMVOCs, but project growth in methane, especially in RCP 8.5 (Wild et al., 2012; Eyring et al., 2013b; Young et al., 2013).

\subsection{Impacts of climate change and stratospheric ozone recovery}

Although the fEmis simulation was designed to assess the impacts of climate change on the atmosphere (Eyring et al., 2013a), there is a discrepancy with respect to methane's dual roles as a greenhouse gas and ozone precursor when it comes to analysing tropospheric ozone, as discussed in the preced- 

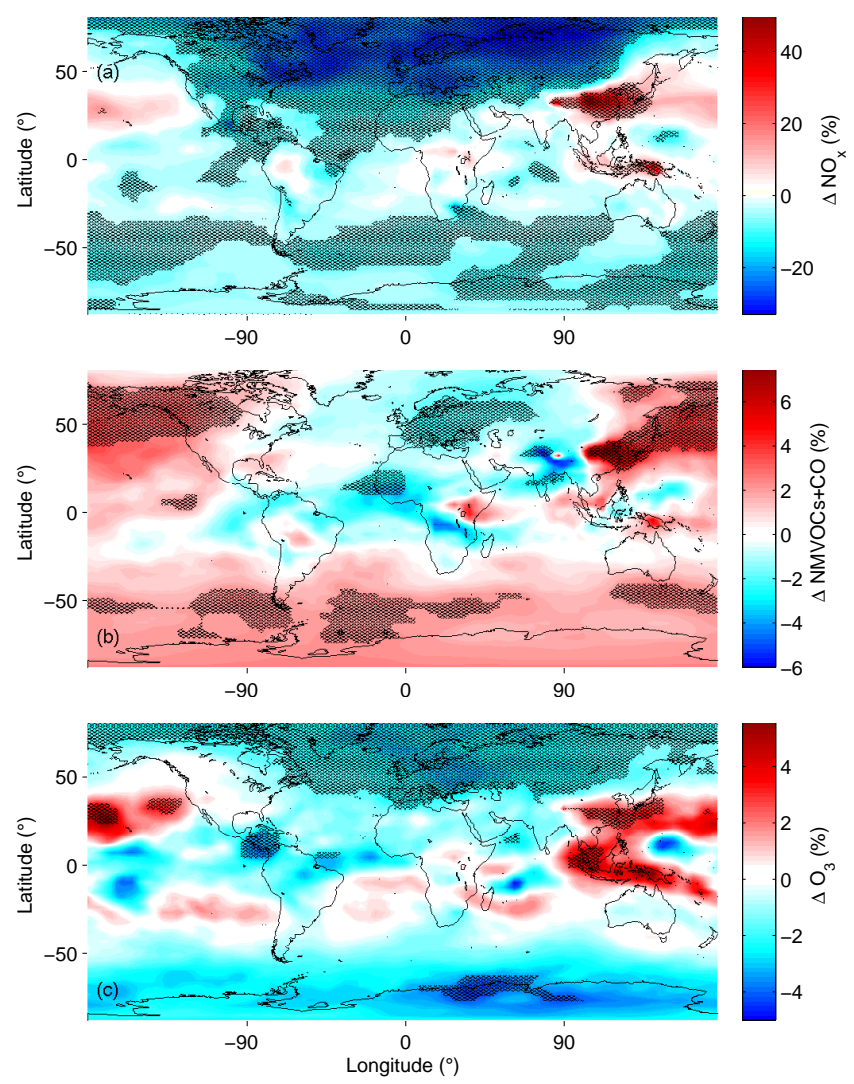

Figure 6. Changes between the 2000s and 2020s decades (2020s minus 2000s) in the REF-C2 simulation at $500 \mathrm{hPa}$ for: (a) $\mathrm{NO}_{x}$; (b) NMVOCs + CO; (c) ozone. Shading indicates that the difference is statistically significant at the $95 \%$ level of confidence.

ing section. However, given that ozone in the $\mathrm{fCH}_{4}$ simulation is the same in the 1960s and 2090s (Fig. 5c), this implies that the effects of climate change and stratospheric ozone recovery on ozone in the mid-troposphere are either negligible, or offset one another.

Climate change is thought to lead to tropospheric ozone decreases, due to increasing temperature and humidity, which accelerates the ozone destruction reactions (e.g. Toumi et al., 1996; Grewe et al., 2001; Doherty et al., 2013; Morgenstern et al., 2013). Figure 8a shows the ozone change at $500 \mathrm{hPa}$ in the fEmis simulation between the 1960s and 2090s. The change is statistically significant at the $95 \%$ confidence level almost everywhere. Here, with $\mathrm{NO}_{x}$, NMVOCs and $\mathrm{CO}$ fixed in the fEmis simulation, ozone increases up to $6 \mathrm{ppb}$ (a global-mean increase of $6 \%$ ). The only exceptions are south of $50^{\circ} \mathrm{S}$, where it remains unchanged and over the equatorial Pacific, where decreases of up to $2 \mathrm{ppb}$ are seen. As discussed in Sect. 3.2, the $\mathrm{H}_{2} \mathrm{O}+\mathrm{O}\left({ }^{1} \mathrm{D}\right) \mathrm{Re}$ action (R5) is very important for ozone loss over the remote tropical Pacific Ocean, and this reaction becomes faster over the period 1960-2100 as the troposphere becomes increasingly warm and humid (e.g. Zeng et al., 2010; Stevenson et
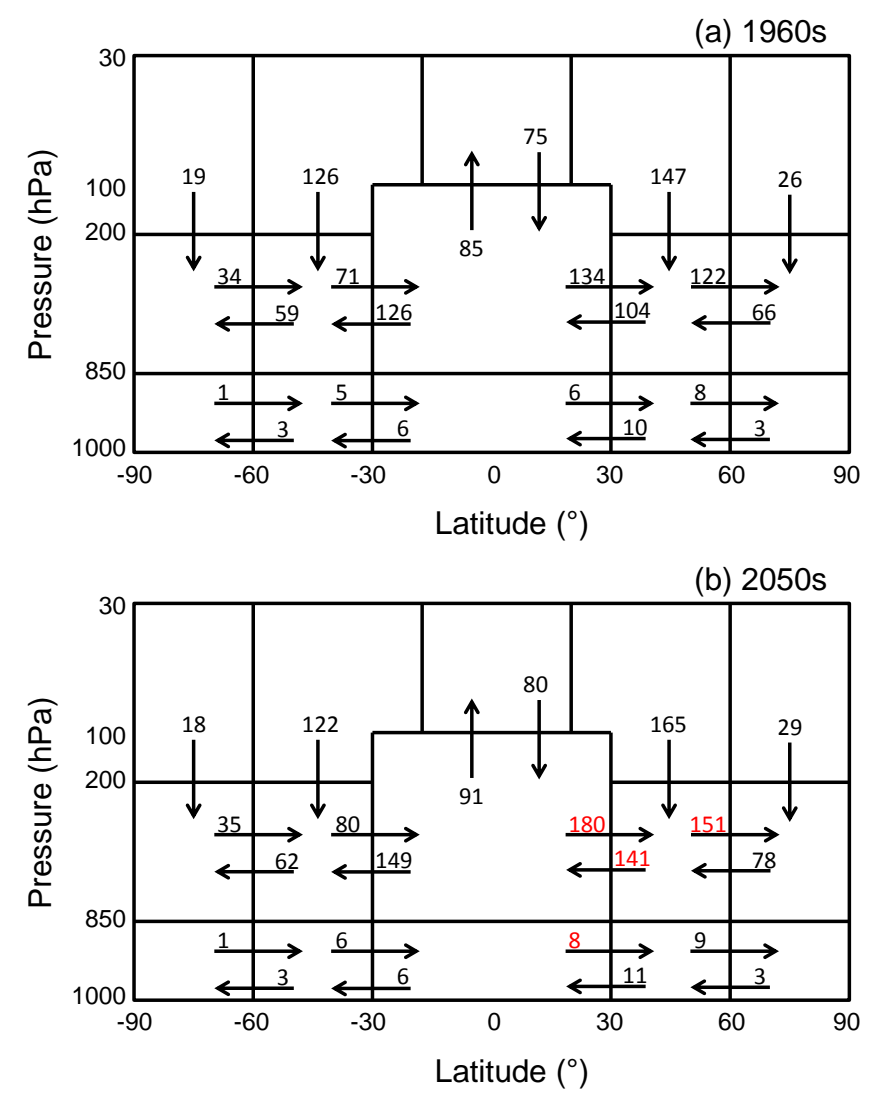

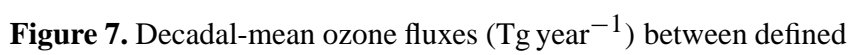
tracer regions for (a) the 1960s and (b) the 2050s in the REF-C2 simulation. Red text in panel (b) indicates an increase of more than $20 \%$ from the same quantity in (a).

al., 2013). Figure $8 \mathrm{~b}$ shows the change in the ozone production:loss ratio $(\mathrm{R} 1+\mathrm{R} 2) /(\mathrm{R} 3+\mathrm{R} 4+\mathrm{R} 5)$ between the 1960s and 2090s. This ratio decreases everywhere due to the increased rate of ozone loss reactions, particularly at northern midlatitudes. Clearly temperature and humidity play an important role for ozone in the tropical Pacific (leading to less ozone), however ozone production resulting from the increase in methane is more important elsewhere, despite the increased rate of the ozone destruction reactions.

Alongside methane, two further factors contribute to the ozone increase in the fEmis simulation, although their influence is small: $\mathrm{NO}_{x}$ emissions from lightning, and STE. STE is projected to increase through the 21 st century, because (a) as lower stratospheric ozone abundances increase, there is more ozone in the stratosphere available to be transported to the troposphere, and (b) the overall meridional circulation, the Brewer-Dobson circulation, is projected to strengthen (thus transporting more ozone from the stratosphere to the troposphere) (Hegglin and Shepherd, 2009; Zeng et al., 2010). Figure 8c shows the contribution of stratospheric ozone to the ozone budget at $500 \mathrm{hPa}$ in the 1960s, calculated using the lower-stratospheric ozone tracers. The 

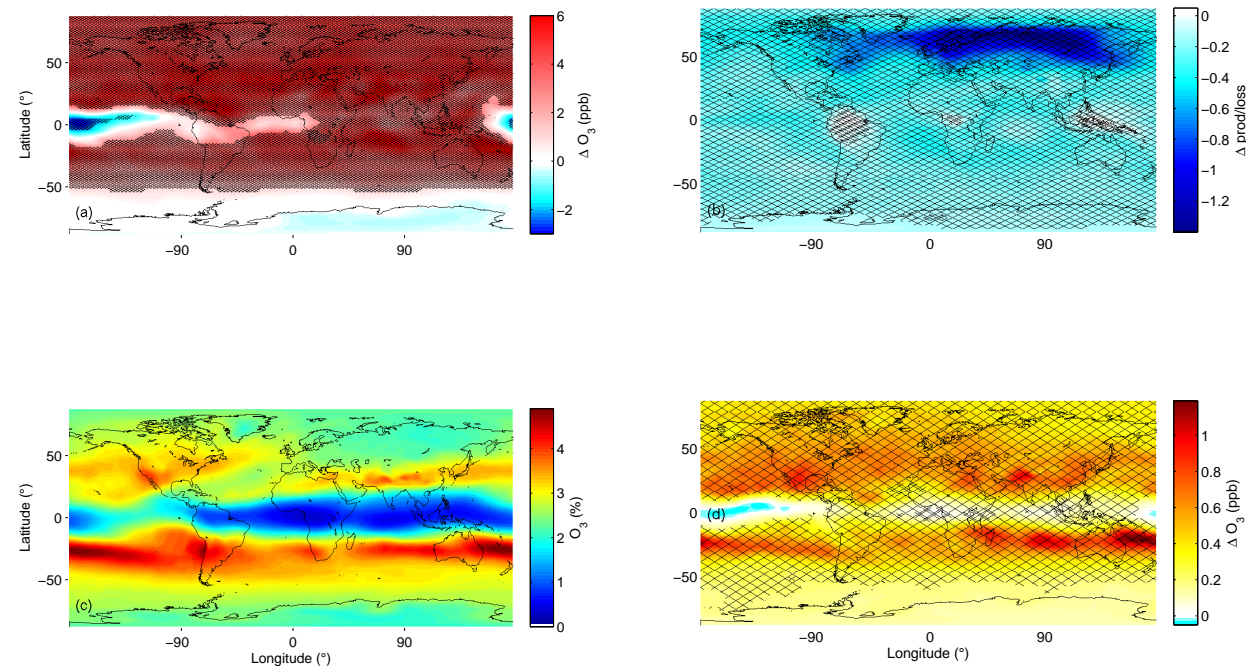

Figure 8. (a) Change in ozone at $500 \mathrm{hPa}$ in the fEmis simulation, 2090s minus 1960s; (b) change in the ratio of ozone production over loss in the fEmis simulation, 2090s minus 1960s; (c) percentage of ozone at $500 \mathrm{hPa}$ which was produced in the lower stratosphere in the fEmis simulation, 1960s decade; (d) absolute change in the amount of ozone at $500 \mathrm{hPa}$ which was produced in the lower stratosphere in the fEmis simulation, 2090s minus 1960s. Shading indicates that the difference is statistically significant at the $95 \%$ level of confidence.

tracers define the lower stratosphere as the region between $30-200 \mathrm{hPa}$ for $30-90^{\circ} \mathrm{N}$ and $30-90^{\circ} \mathrm{S}$, and between 30 $100 \mathrm{hPa}$ for $30^{\circ} \mathrm{N}-30^{\circ} \mathrm{S}$ (Fig. 7), given that the tropopause sits at a lower pressure level in the tropics. In the 1960s, STE contributes between $0.1-5 \%$ of ozone present at $500 \mathrm{hPa}$. We calculate a total flux from the lower stratosphere to the troposphere of $462 \mathrm{Tg} \mathrm{yr}^{-1}$ in the 1960s. This is lower than the mean value from the model studies reviewed by Wild (2007) of $636 \mathrm{Tg} \mathrm{yr}^{-1}$, but still within one standard deviation from their mean. Figure 8d shows the change in the contribution of stratospheric ozone to ozone at $500 \mathrm{hPa}$ between the 1960s and 2090s in the fEmis simulation. STE contributes up to one additional ppb at southern midlatitudes, and this is statistically significant at the $95 \%$ confidence level.

As discussed in Sect. 3.2, methane leads to ozone production in the presence of $\mathrm{NO}_{x}$. Along with humidity and STE, lightning $\mathrm{NO}_{x}$ emissions may increase in a warmer climate, either due to increased frequency of thunderclouds (and therefore lightning), or more intense thunderstorms (Schumann and Huntrieser, 2007; Price 2013). Figure 9a shows lightning $\mathrm{NO}_{x}$ emissions from SOCOL averaged over the 1960s, and shows that most lightning is produced over Africa and South America. Lightning $\mathrm{NO}_{x}$ emissions increase over the continents by $61 \%$ between 1960 and 2100 (Fig. 9b), and by $48 \%$ between 2000 and 2100 . Smyshlyaev et al. (2010) found that ozone increased between 10 and $20 \%$ when lightning $\mathrm{NO}_{x}$ emissions increased by $2 \mathrm{Tg}(\mathrm{N})$ year ${ }^{-1}$ (depending on latitude and season), and up to $90 \%$ with a $20 \mathrm{Tg}(\mathrm{N})$ year ${ }^{-1}$ increase in lightning $\mathrm{NO}_{x}$. Banerjee et al. (2014) calculated increases in lightning $\mathrm{NO}_{x}$ emissions of $33 \%\left(2 \mathrm{Tg}(\mathrm{N})\right.$ year $\left.^{-1}\right)$ and $78 \%\left(4.7 \mathrm{Tg}(\mathrm{N})\right.$ year $\left.^{-1}\right)$ between 2000-2100 in simulations using RCP 4.5 and RCP

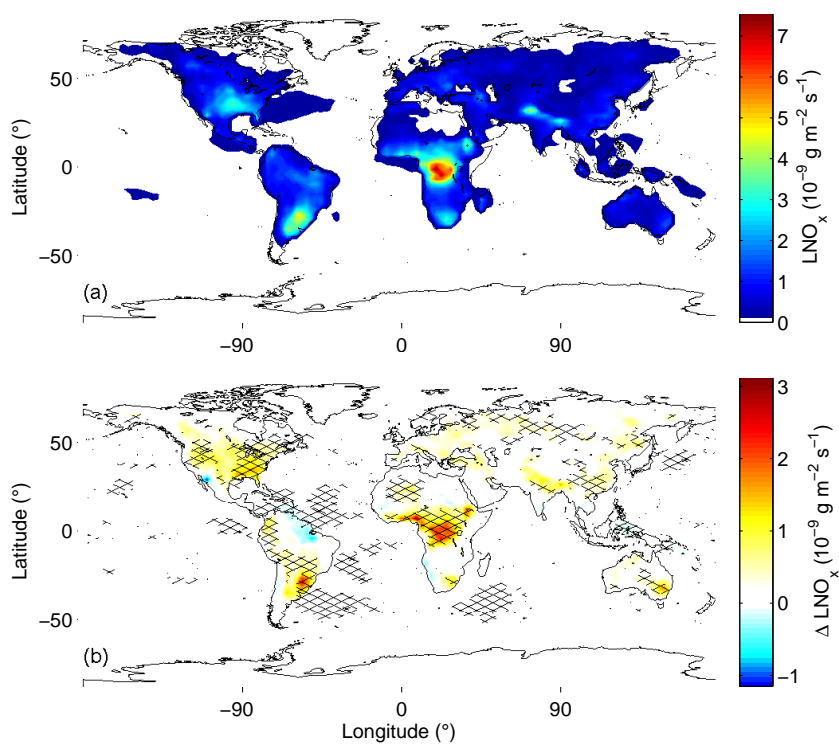

Figure 9. (a) Lightning $\mathrm{NO}_{x}$ emissions in the fEmis simulation, averaged over the 1960s; (b) change in lightning $\mathrm{NO}_{x}$ emissions in the fEmis simulation, 2090s minus 1960s. Shading indicates that the difference is statistically significant at the $95 \%$ level of confidence.

8.5, respectively. In our fEmis simulation (which used RCP 6.0, a scenario of intermediate severity compared to RCP 4.5 and RCP 8.5), we calculate a $48 \%$ increase in lightning $\mathrm{NO}_{x}$ emissions over the same period, which is broadly consistent with their findings. Banerjee et al. (2014) also showed that under RCP 8.5, the increase in lightning $\mathrm{NO}_{x}$ emissions of $78 \%$ caused ozone increases of up to $30 \%$ in the troposphere (maximizing between the equator and $30^{\circ} \mathrm{S}$ ). Although we 
cannot quantify ozone increases induced by lightning $\mathrm{NO}_{x}$ emissions in our simulations, the studies referred to here indicate the likely magnitude of increase (20-30\%). Together with STE, ozone increases induced by lightning $\mathrm{NO}_{x}$ emissions are largely offset by the temperature-induced increased rates of ozone destruction in the troposphere. Finally, we note that the results also depend on the chosen lightning parametrization, which is coupled to the cloud top heights; Grewe (2009) showed that lightning $\mathrm{NO}_{x}$ emissions might also slightly decrease, when stronger but fewer convective events occur in a future climate.

\section{Conclusions}

We have presented three CCM simulations covering the period 1960-2100, where the only factors differing in the model setup were the ozone precursor emissions $\left(\mathrm{NO}_{x}\right.$, NMVOCs, $\mathrm{CO}$ and $\mathrm{CH}_{4}$ ). The tropospheric extension to the SOCOL CCM is still new and with 17 NMVOCs only moderately sophisticated relative to some of the better-established tropospheric chemistry models. However, the results presented here compare favourably with previous work.

In the REF-C2 simulation, which used RCP 6.0 greenhouse gases and ozone precursors, the maximum impact of ozone precursors on tropospheric ozone occurs between 1990 and 2060, when global-mean ozone in the free troposphere increases by $23 \%$ from 1960 levels. Although decreasing emissions of ozone precursor gases over Europe and North America lead to local reductions in ozone in the early 21 st century, large increases in precursor gas emissions from Asia, combined with ozone's ability to be transported on inter-continental scales within the troposphere, lead to a 70year period between 1990-2060 in which ozone abundances at northern midlatitudes are constantly elevated. In the late 21 st century, reductions in ozone precursor gases, especially $\mathrm{NO}_{x}$, lead to decreases in tropospheric ozone globally. However, global-mean concentrations are still $8 \%$ higher in the 2090s compared with the 1960s.

In the fEmis (fixed ozone precursor emissions) simulation, global-mean ozone increases by $6 \%$ between 1960 and 2100 , mostly because methane concentrations were not held constant. A $\mathrm{fCH}_{4}$ sensitivity simulation with all ozone precursors (including methane) held constant shows that tropospheric ozone concentrations are the same in 2100 as in 1960. Increased flux of ozone from the stratosphere to the troposphere, and increased emissions of $\mathrm{NO}_{x}$ from lightning in a warmer climate contribute to increases in tropospheric ozone through the 21 st century, although their effects are largely offset by temperature-induced increased rates of ozone destruction in the troposphere. Other climate-change related factors we have not examined include biogenic emissions, which are thought to increase with temperature, but are not considered in our simulations because SOCOL does not include an interactive scheme for biogenic emissions. Notably, we have considered only a single climate change scenario (RCP 6.0), and the impacts of climate change will differ under different climate scenarios. We furthermore reiterate that emissions of ozone precursor gases are also a significant source of uncertainty in our results.

Overall, and given the assumptions inherent in the climate and ozone precursor emissions scenarios we used, anthropogenic $\mathrm{NO}_{x}$ emissions have the largest influence on tropospheric ozone in our simulations. Methane has the second largest influence, which is approximately one-third that of anthropogenic $\mathrm{NO}_{x}$ emissions. We therefore conclude that emission policies globally have the largest role to play in determining tropospheric ozone evolution through the $21 \mathrm{st}$ century.

Acknowledgements. L. E. Revell was supported under the ETH Zurich Postdoctoral Fellowship Program. A. Coulon and A. Stenke are supported by the Competence Center Environment and Sustainability (CCES) under the project MAIOLICA-2. AS is furthermore supported by the SNSF under grant no. 200021_138037/1 (FuMES). F. Tummon is supported by a SNSF post-doctoral grant. We acknowledge the free use of tropospheric $\mathrm{NO}_{2}$ column data from the OMI sensor from www.temis.nl. The authors would like to thank two anonymous reviewers for their helpful comments on this paper.

Edited by: M. Van Roozendael

\section{References}

Anet, J. G., Rozanov, E. V., Muthers, S., Peter, T., Brönnimann, S., Arfeuille, F., Beer, J., Shapiro, A. I., Raible, C. C., Steinhilber, F., and Schmutz, W. K.: Impact of a potential 21st century "grand solar minimum" on surface temperatures and stratospheric ozone, Geophys. Res. Lett., 40, 4420-4425, doi:10.1002/grl.50806, 2013.

Auvray, M. and Bey, I.: Long-range transport to Europe: Seasonal variations and implications for the European ozone budget, J. Geophys. Res., 110, D11303, doi:10.1029/2004JD005503, 2005.

Auvray, M., Bey, I., Llull, E., Schultz, M. G., and Rast, S.: A model investigation of tropospheric ozone chemical tendencies in long-range transported pollution plumes, J. Geophys. Res., 112, D05304, doi:10.1029/2006JD007137, 2007.

Avallone, L. M. and Prather, M. J.: Photochemical evolution of ozone in the lower tropical stratosphere, J. Geophys. Res., 101, 1457-1461, doi:10.1029/95JD03010, 1996.

Banerjee, A., Archibald, A. T., Maycock, A. C., Telford, P., Abraham, N. L., Yang, X., Braesicke, P., and Pyle, J. A.: Lightning $\mathrm{NO}_{x}$, a key chemistry-climate interaction: impacts of future climate change and consequences for tropospheric oxidizing capacity, Atmos. Chem. Phys., 14, 9871-9881, doi:10.5194/acp-149871-2014, 2014.

Bekki, S., Bodeker, G. E. (Coordinating Lead Authors), Bais, A. F., Butchart, N., Eyring, V., Fahey, D. W., Kinnison, D. E., Langematz, U., Mayer, B., Portmann, R.W., Rozanov, E., Braesicke, P., Charlton-Perez, A. J., Chubarova, N. E., Cionni, I., Diaz, S. B., 
Gillett, N. P., Giorgetta, M. A., Komala, N., Lefèvre, F., McLandress, C., Perlwitz, J., Peter, T., and Shibata, K.: Future ozone and its impact on surface UV, Chapter 3 in: Scientific Assessment of Ozone Depletion: 2010, Global Ozone Research and Monitoring Project - Report No. 52, 516 pp., World Meteorological Organization, Geneva, Switzerland, 2011.

Boersma, K. F., Eskes, H. J., Veefkind, J. P., Brinksma, E. J., van der A, R. J., Sneep, M., van den Oord, G. H. J., Levelt, P. F., Stammes, P., Gleason, J. F., and Bucsela, E. J.: Near-real time retrieval of tropospheric $\mathrm{NO}_{2}$ from OMI, Atmos. Chem. Phys., 7, 2103-2118, doi:10.5194/acp-7-2103-2007, 2007.

Bowman, K. W., Shindell, D. T., Worden, H. M., Lamarque, J.F., Young, P. J., Stevenson, D. S., Qu, Z., de la Torre, M., Bergmann, D., Cameron-Smith, P. J., Collins, W. J., Doherty, R., Dalsøren, S. B., Faluvegi, G., Folberth, G., Horowitz, L. W., Josse, B. M., Lee, Y. H., MacKenzie, I. A., Myhre, G., Nagashima, T., Naik, V., Plummer, D. A., Rumbold, S. T., Skeie, R. B., Strode, S. A., Sudo, K., Szopa, S., Voulgarakis, A., Zeng, G., Kulawik, S. S., Aghedo, A. M., and Worden, J. R.: Evaluation of ACCMIP outgoing longwave radiation from tropospheric ozone using TES satellite observations, Atmos. Chem. Phys., 13, 40574072, doi:10.5194/acp-13-4057-2013, 2013.

Butchart, N., Cionni, I., Eyring, V., Shepherd, T. G., Waugh, D. W., Akiyoshi, H., Austin, J., Brühl, C., Chipperfield, M. P., Cordero, E., Dameris, M., Deckert, R., Dhomse, S., Frith, S. M., Garcia, R. R., Gettelman, A., Giorgetta, M. A., Kinnison, D. E., Li, F., Mancini, E., McLandress, C., Pawson, S., Pitari, G., Plummer, D. A., Rozanov, E., Sassi, F., Scinocca, J. F., Shibata, K., Steil, B., and Tian, W.: Chemistry-climate model simulations of twentyfirst century stratospheric climate and circulation changes, J. Climate, 23, 5349-5374, doi:10.1175/2010JCLI3404.1, 2010.

Cai, W., Borlace, S., Lengaigne, M., van Rensch, P., Collins, M., Vecchi, G., Timmermann, A., Santoso, A., McPhaden, M. J., Wu, L., England, M. H., Wang, G., Guilyardi, E., and Jin, F.-F.: Increasing frequency of extreme El Niño events due to greenhouse warming, Nat. Clim. Change, 4, 111-116, doi:10.1038/nclimate2100, 2014.

Chang, J. S., Brost, R. A., Isaksen, I. S. A., Madronich, S., Middleton, P., Stockwell, W. R., and Walcek, C. J.: A threedimensional Eulerian acid deposition model: Physical concepts and formulation, J. Geophys. Res., 92, 14681-14700, doi:10.1029/JD092iD12p14681, 1987.

Chang, T. Y.: Rain and snow scavenging of $\mathrm{HNO}_{3}$ vapor in the atmosphere, Atmos. Environ., 18(1), 191-197, doi:10.1016/00046981(84)90242-7, 1984.

Christian, H. J., Blakeslee, R. J., Boccippio, D. J., Boeck, W. L., Buechler, D. E., Driscoll, K. T., Goodman, S. J., Hall, J. M., Koshak, W. J., Mach, D. M., and Stewart, M. F.: Global frequency and distribution of lightning as observed from space by the Optical Transient Detector, J. Geophys. Res., 108, 4005, doi:10.1029/2002JD002347, 2003.

Denman, K. L., Brasseur, G., Chidthaisong, A., Ciais, P., Cox, P. M., Dickinson, R. E., Hauglustaine, D., Heinze, C., Holland, E., Jacob, D., Lohmann, U., Ramachandran, S., da Silva Dias, P. L., Wofsy, S. C., and Zhang, X.: Couplings between changes in the climate system and biogeochemistry, Chapter 7 in Climate Change 2007: the Physical Science Basis. Contribution of Working Group I to the Fourth Assessment Report of the Intergovernmental Panel on Climate Change, edited by: Solomon, S., Qin,
D., Manning, M., Chen, Z., Marquis, M., Averyt, K. B., Tignor, M., and Miller, H. L., Cambridge University Press, Cambridge, United Kingdom and New York, NY, USA, 2007.

Dentener, F. J. and Crutzen, P. J.: Reaction of $\mathrm{N}_{2} \mathrm{O}_{5}$ on tropospheric aerosols: Impact on the global distributions of $\mathrm{NO}_{x}, \mathrm{O}_{3}$ and OH, J. Geophys., Res., 98, 7149-7163, doi:10.1029/92JD02979, 1993.

Derwent, R. G., Stevenson, D. S., Doherty, R. M., Collins, W. J., and Sanderson, M. G.: How is surface ozone in Europe linked to Asian and North American $\mathrm{NO}_{x}$ emissions?, Atmos. Environ., 42, 7412-7422, doi:10.1016/j.atmosenv.2008.06.037, 2008.

Doherty, R. M., Wild, O., Shindell, D. T., Zeng, G., MacKenzie, I. A., Collins, W. J., Fiore, A. M., Stevenson, D. S., Dentener, F. J., Schultz, M. G., Hess, P., Derwent, R. G., and Keating, T. J.: Impacts of climate change on surface ozone and intercontinental ozone pollution: A multi-model study, J. Geophys. Res., 118, 3744-3763, doi:10.1002/jgrd.50266, 2013.

Egorova, T. A., Rozanov, E. V., Zubov, V. A., and Karol, I. L.: Model for investigating ozone trends (MEZON), Izv. Atmos. Ocean. Phys., 39, 277-292, 2003.

Ehhalt, D., Prather, M., Dentener, F., Derwent, R., Dlugokencky, E., Holland, E., Isaksen, I., Katima, J., Kirchhoff, V., Matson, P., Midgley, P., and Wang, M.: Atmospheric chemistry and greenhouse gases, Chapter 4 in Climate Change 2001: The Scientific Basis. Contribution of Working Group I to the Third Assessment Report of the Intergovernmental Panel on Climate Change, edited by: Houghton, J. T., Ding, Y., Griggs, D. J., Noguer, M., van der Linden, P. J., Dai, X., Maskell, K., and Johnson, C. A, Cambridge University Press, Cambridge, United Kingdom and New York, NY, USA, 2001.

Evans, M. J. and Jacob, D. J.: Impact of new laboratory studies of $\mathrm{N}_{2} \mathrm{O}_{5}$ hydrolysis on global model budgets of tropospheric nitrogen oxides, ozone and OH, Geophys. Res. Lett., 32, L09813, doi:10.1029/2005GL022469, 2005.

Eyring, V., Lamarque, J.-F., Hess, P., Arfeuille, F., Bowman, K., Chipperfield, M. P., Duncan, B., Fiore, A., Gettelman, A., Giorgetta, M. A., Granier, C., Hegglin, M., Kinnison, D., Kunze, M., Langematz, U., Luo, B., Martin, R., Matthes, K., Newman, P. A., Peter, T., Robock, A., Ryerson, T., Saiz-Lopez, A., Salawitch, R., Schultz, M., Shepherd, T. G., Shindell, D., Staehelin, J., Tegtmeier, S., Thomason, L., Tilmes, S., Vernier, J.-P., Waugh, D. W., and Young, P. J.: Overview of IGAC/SPARC Chemistry-Climate Model Initiative (CCMI) Community Simulations in Support of Upcoming Ozone and Climate Assessments, SPARC Newsletter no. 40, ISSN 1245-4680, 48-66, 2013a.

Eyring, V., Arblaster, J. M., Cionni, I., Sedláček, J., Perlwitz, J., Young, P. J., Bekki, S., Bergmann, D., Cameron-Smith, P., Collins, W. J., Faluvegi, G., Gottschaldt, K.-D., Horowitz, L. W., Kinnison, D. E., Lamarque, J.-F., Marsh, D. R., SaintMartin, D., Shindell, D. T., Sudo, K., Szopa, S., and Watanabe, S.: Long-term ozone changes and associated climate impacts in CMIP5 simulations, J. Geophys. Res., 118, 5029-5060, doi:10.1002/jgrd.50316, 2013b.

Gao, R. S., Rosenlof, K. H., Fahey, D. W., Wennberg, P. O., Hintsa, E. J., and Hanisco, T. F.: OH in the tropical upper troposphere and its relationships to solar radiation and reactive nitrogen, J. Atmos. Chem., 71, 55-64, doi:10.1007/s10874-014-9280-2, 2014.

Garny, H., Grewe, V., Dameris, M., Bodeker, G. E., and Stenke, A.: Attribution of ozone changes to dynamical and chemical pro- 
cesses in CCMs and CTMs, Geosci. Model Dev., 4, 271-286, doi:10.5194/gmd-4-271-2011, 2011.

Grewe, V.: The origin of ozone, Atmos. Chem. Phys., 6, 1495-1511, doi:10.5194/acp-6-1495-2006, 2006.

Grewe, V.: Impact of Lightning on Air Chemistry and Climate, in: Lightning: Principles, Instruments and Applications Review of Modern Lightning Research, edited by: Betz, H. D., Schumann, U., and Laroche, P., 524-551, Springer Verlag, 2009.

Grewe, V., Dameris, M., Hein, R., Sausen, R., and Steil, B.: Future changes of the atmospheric composition and the impact of climate change, Tellus, 53B, 103-121, 2001.

Guenther, A., Karl, T., Harley, P., Wiedinmyer, C., Palmer, P. I., and Geron, C.: Estimates of global terrestrial isoprene emissions using MEGAN (Model of Emissions of Gases and Aerosols from Nature), Atmos. Chem. Phys., 6, 3181-3210, doi:10.5194/acp-63181-2006, 2006.

Hegglin, M. I. and Shepherd, T. G.: Large climate-induced changes in ultraviolet index and stratosphere-to-troposphere ozone flux, Nat. Geosci., 2, 687-691, doi:10.1038/ngeo604, 2009.

Ho, S., Edwards, D. P., Gille, J. C., Luo, M., Osterman, G. B., Kulawik, S. S., and Worden, H.: A global comparison of carbon monoxide profiles and column amounts from Tropospheric Emission Spectrometer (TES) and Measurements of Pollution in the Troposphere (MOPITT), J. Geophys. Res., 114, D21307, doi:10.1029/2009JD012242, 2009.

Huijnen, V., Eskes, H. J., Poupkou, A., Elbern, H., Boersma, K. F., Foret, G., Sofiev, M., Valdebenito, A., Flemming, J., Stein, O., Gross, A., Robertson, L., D’Isidoro, M., Kioutsioukis, I., Friese, E., Amstrup, B., Bergstrom, R., Strunk, A., Vira, J., Zyryanov, D., Maurizi, A., Melas, D., Peuch, V.-H., and Zerefos, C.: Comparison of $\mathrm{OMI} \mathrm{NO}_{2}$ tropospheric columns with an ensemble of global and European regional air quality models, Atmos. Chem. Phys., 10, 3273-3296, doi:10.5194/acp-10-3273-2010, 2010.

Kawase, H., Nagashima, T., Sudo, K., and Nozawa, T.: Future changes in tropospheric ozone under Representative Concentration Pathways (RCPs), Geophys. Res. Lett., 38, L05801, doi:10.1029/2010GL046402, 2011.

Kley, D., Crutzen, P. J., Smit, H. G. J., Vömel, H., Oltmans, S. J., Grassl, H., and Ramanathan, V.: Observations of near-zero ozone concentrations over the convective Pacific: Effects on air chemistry, Science, 274, 230-233, doi:10.1126/science.274.5285.230, 1996.

Lamarque, J.-F., Bond, T. C., Eyring, V., Granier, C., Heil, A., Klimont, Z., Lee, D., Liousse, C., Mieville, A., Owen, B., Schultz, M. G., Shindell, D., Smith, S. J., Stehfest, E., Van Aardenne, J., Cooper, O. R., Kainuma, M., Mahowald, N., McConnell, J. R., Naik, V., Riahi, K., and van Vuuren, D. P.: Historical (1850-2000) gridded anthropogenic and biomass burning emissions of reactive gases and aerosols: methodology and application, Atmos. Chem. Phys., 10, 7017-7039, doi:10.5194/acp10-7017-2010, 2010.

Lamarque, J.-F., Shindell, D. T., Josse, B., Young, P. J., Cionni, I., Eyring, V., Bergmann, D., Cameron-Smith, P., Collins, W. J., Doherty, R., Dalsoren, S., Faluvegi, G., Folberth, G., Ghan, S. J., Horowitz, L. W., Lee, Y. H., MacKenzie, I. A., Nagashima, T., Naik, V., Plummer, D., Righi, M., Rumbold, S. T., Schulz, M., Skeie, R. B., Stevenson, D. S., Strode, S., Sudo, K., Szopa, S., Voulgarakis, A., and Zeng, G.: The Atmospheric Chemistry and Climate Model Intercomparison Project (ACCMIP): overview and description of models, simulations and climate diagnostics, Geosci. Model Dev., 6, 179-206, doi:10.5194/gmd-6-179-2013, 2013.

Lang, C., Waugh, D. W., Olsen, M. A., Douglass, A. R., Liang, Q., Nielsen, J. E., Oman, L. D., Pawson, S., and Stolarski, R. S.: The impact of greenhouse gases on past changes in tropospheric ozone, J. Geophys. Res., 117, D23304, doi:10.1029/2012JD018293, 2012.

Lin, M., Horowitz, L. W., Oltmans, S. J., Fiore, A. M., and Fan, S.: Tropospheric ozone trends at Mauna Loa Observatory tied to decadal climate variability, Nat. Geosci., 7, 136-143, doi:10.1038/NGEO2066, 2014.

Lin, S. J. and Rood, R. B.: Multidimensional fluxform semi-Lagrangian transport schemes, Mon. Weather Rev., 124, 2046-2070, doi:10.1175/15200493(1996)124<2046:MFFSLT>2.0.CO;2, 1996.

Masui, T., Matsumoto, K., Hijioka, Y., Kinoshita, T., Nozawa, T., Ishiwatari, S., Kato, E., Shukla, P. R., Yamagata, Y., and Kainuma, M.: An emission pathway for stabilization at $6 \mathrm{Wm}^{-2}$ radiative forcing, Climatic Change, 109, 59-76, doi:10.1007/s10584-011-0150-5, 2011.

Meehl, G. A., Washington, W. M., Arblaster, J. M., Hu, A., Teng, H., Kay, J. E., Gettelman, A., Lawrence, D. M., Sanderson, B. M., and Strand, W. G.: Climate change projections in CESM1(CAM5) compared to CCSM4, J. Climate, 26, 62876308, doi:10.1175/JCLI-D-12-00572.1, 2013.

Morgenstern, O., Zeng, G., Abraham, N. L., Telford, P. J., Braesicke, P., Pyle, J. A., Hardiman, S. C., O’Connor, F. M., and Johnson, C. E.: Impacts of climate change, ozone recovery, and increasing methane on surface ozone and the tropospheric oxidizing capacity, J. Geophys. Res., 118, 1028-1041, doi:10.1029/2012JD018382, 2013.

Murray, L. T., Jacob, D. J., Logan, J. A., Hudman, R. C., and Koshak, W. J.: Optimized regional and interannual variability of lightning in a global chemical transport model constrained by LIS/OTD satellite data, J. Geophys. Res., 117, D20307, doi:10.1029/2012jd017934, 2012.

Myhre, G., Shindell, D., Bréon, F.-M., Collins, W., Fuglestvedt, J., Huang, J., Koch, D., Lamarque, J.-F., Lee, D., Mendoza, B., Nakajima, T., Robock, A., Stephens, G., Takemura, T., and Zhang, H.: Anthropogenic and natural radiative forcing, Chapter 8 in Climate Change 2013: The Physical Science Basis. Contribution of Working Group I to the Fifth Assessment Report of the Intergovernmental Panel on Climate Change, edited by: Stocker, T. F., Qin, D., Plattner, G.-K., Tignor, M., Allen, S. K., Boschung, J., Nauels, A., Xia, Y., Bex, V., and Midgley, P. M., Cambridge University Press, Cambridge, United Kingdom and New York, NY, USA, 2013.

Naik, V., Voulgarakis, A., Fiore, A. M., Horowitz, L. W., Lamarque, J.-F., Lin, M., Prather, M. J., Young, P. J., Bergmann, D., Cameron-Smith, P. J., Cionni, I., Collins, W. J., Dalsøren, S. B., Doherty, R., Eyring, V., Faluvegi, G., Folberth, G. A., Josse, B., Lee, Y. H., MacKenzie, I. A., Nagashima, T., van Noije, T. P. C., Plummer, D. A., Righi, M., Rumbold, S. T., Skeie, R., Shindell, D. T., Stevenson, D. S., Strode, S., Sudo, K., Szopa, S., and Zeng, G.: Preindustrial to present-day changes in tropospheric hydroxyl radical and methane lifetime from the Atmospheric Chemistry and Climate Model Intercomparison Project (ACCMIP), Atmos. 
Chem. Phys., 13, 5277-5298, doi:10.5194/acp-13-5277-2013, 2013.

Parrish, D. D., Lamarque, J.-F., Naik, V., Horowitz, L. Shindell, D. T., Staehelin, J., Derwent, R., Cooper, O. R., Tanimoto, H., Volz-Thomas, A., Gilge, S., Scheel, H.-E., Steinbacher, M., and Fröhlich, M.: Long-term changes in lower tropospheric baseline ozone concentrations: Comparing chemistry-climate models and observations at northern midlatitudes, J. Geophys. Res., 119, 5719-5736, doi:10.1002/2013JD021435, 2014.

Poeschl, U., von Kuhlmann, R., Poisson, N., and Crutzen, P. J.: Development and intercomparison of condensed isoprene oxidation mechanisms for global atmospheric modeling, J. Atmos. Chem., 37, 29-52, doi:10.1023/A:1006391009798, 2000.

Price, C. and Rind, D.: A simple lightning parameterization for calculating global lightning distributions, J. Geophys. Res., 97, 9919-9933, doi:10.1029/92JD00719, 1992.

Price, C. G.: Lightning Applications in Weather and Climate Research, Surv. Geophys., 34, 755-767, doi:10.1007/s10712-0129218-7, 2013.

Rayner, N. A., Parker, D. E., Horton, E. B., Folland, C. K., Alexander, L. V., Rowell, D. P., Kent, E. C., and Kaplan, A.: Global analyses of sea surface temperature, sea ice, and night marine air temperature since the late nineteenth century, J. Geophys. Res., 108, 4407, doi:10.1029/2002JD002670, 2003.

Revell, L. E., Bodeker, G. E., Smale, D., Lehmann, R., Huck, P. E., Williamson, B. E., Rozanov, E., and Struthers, H.: The effectiveness of $\mathrm{N}_{2} \mathrm{O}$ in depleting stratospheric ozone, Geophys. Res. Lett., 39, L15806, doi:10.1029/2012GL052143, 2012.

Rex, M., Wohltmann, I., Ridder, T., Lehmann, R., Rosenlof, K., Wennberg, P., Weisenstein, D., Notholt, J., Krüger, K., Mohr, V., and Tegtmeier, S.: A tropical West Pacific $\mathrm{OH}$ minimum and implications for stratospheric composition, Atmos. Chem. Phys., 14, 4827-4841, doi:10.5194/acp-14-4827-2014, 2014.

Richards, N. A. D., Osterman, G. B., Browell, E. V., Hair, J. W., Avery, M., and Li, Q.: Validation of Tropospheric Emission Spectrometer ozone profiles with aircraft observations during the Intercontinental Chemical Transport Experiment-B, J. Geophys. Res., 113, D16S29, doi:10.1029/2007JD008815, 2008.

Roeckner, E., Bäuml, G., Bonaventura, L., Brokopf, R., Esch, M., Giorgetta, M., Hagemann, S., Kirchner, I., Kornblueh, L., Manzini, E., Rhodin, A., Schlese, U., Schulzweida, U., and Tompkins, A.: The atmospheric general circulation model ECHAM 5. Part I: Model description, Max-PlanckInstitut für Meteorologie, Hamburg, Report No. 349, available at: http://www.mpimet.mpg.de/fileadmin/publikationen/Reports/ max_scirep_349.pdf (last access: 21 May 2015), 2003.

Rozanov, E., Schlesinger, M. E., Zubov, V., Yang, F., and Andronova, N. G.: The UIUC three-dimensional stratospheric chemical transport model: Description and evaluation of the simulated source gases and ozone, J. Geophys. Res., 104, 11755011781, 1999.

Schumann, U. and Huntrieser, H.: The global lightning-induced nitrogen oxides source, Atmos. Chem. Phys., 7, 3823-3907, doi:10.5194/acp-7-3823-2007, 2007.

Seinfeld, J. H. and Pandis, S. N.: Atmospheric Chemistry and Physics: From Air Pollution to Climate Change, John Wiley and Sons, Inc., Hoboken, New Jersey, USA, 2nd Edn., 2006.

Shindell, D. T., Faluvegi, G., Koch, D. M., Schmidt, G. A., Unger, N., and Bauer, S. E.: Improved attribution

of climate forcing to emissions, Science, 326, 716-718, doi:10.1126/science.1174760, 2009.

Silva, R. A., West, J. J., Zhang, Y., Anenberg, S. C., Lamarque, J.F., Shindell, D. T., Collins, W. J., Dalsoren, S., Faluvegi, G., Folberth, G., Horowitz, L. W., Nagashima, T., Naik, V., Rumbold, S., Skeie, R., Sudo, K., Takemura, T., Bergmann, D., CameronSmith, P., Cionni, I., Doherty, R. M., Eyring, V., Josse, B., MacKenzie, I. A., Plummer, D., Righi, M., Stevenson, D. S., Strode, S., Szopa, S., and Zeng, G.: Global premature mortality due to anthropogenic outdoor air pollution and the contribution of past climate change, Environ. Res. Lett., 8, 034005 , doi:10.1088/1748-9326/8/3/034005, 2013.

Singh, H. B., Gregory, G. L., Anderson, B., Browell, E., Sachse, G W., Davis, D. D., Crawford, J., Bradshaw, J. D., Talbot, R., Blake, D. R., Thornton, D., Newell, R., and Merrill, J.: Low ozone in the marine boundary layer of the tropical Pacific Ocean: Photochemical loss, chlorine atoms, and entrainment, J. Geophys. Res., 101, 1907-1917, doi:10.1029/95JD01028, 1996.

Smyshlyaev, S. P., Mareev, E. A., and Galin, V. Ya.: Simulation of the impact of thunderstorm activity on atmospheric gas composition, Izv. Atmos. Ocean. Phys., 46, 451-467, 2010.

SPARC CCMVal: SPARC Report on the Evaluation of ChemistryClimate Models, edited by: Eyring, V., Shepherd, T. G., and Waugh, D. W., SPARC Report No. 5, WCRP-132, WMO/TD-No. 1526, available at: http://www.sparc-climate. org/publications/sparc-reports/sparc-report-no5/ (last access: 21 May 2015), 2010.

Stenke, A., Schraner, M., Rozanov, E., Egorova, T., Luo, B., and Peter, T.: The SOCOL version 3.0 chemistry-climate model: description, evaluation, and implications from an advanced transport algorithm, Geosci. Model Dev., 6, 1407-1427, doi:10.5194/gmd-6-1407-2013, 2013.

Stevenson, D. S., Young, P. J., Naik, V., Lamarque, J.-F., Shindell, D. T., Voulgarakis, A., Skeie, R. B., Dalsoren, S. B., Myhre, G., Berntsen, T. K., Folberth, G. A., Rumbold, S. T., Collins, W. J., MacKenzie, I. A., Doherty, R. M., Zeng, G., van Noije, T. P. C., Strunk, A., Bergmann, D., Cameron-Smith, P., Plummer, D. A., Strode, S. A., Horowitz, L., Lee, Y. H., Szopa, S., Sudo, K., Nagashima, T., Josse, B., Cionni, I., Righi, M., Eyring, V., Conley, A., Bowman, K. W., Wild, O., and Archibald, A.: Tropospheric ozone changes, radiative forcing and attribution to emissions in the Atmospheric Chemistry and Climate Model Intercomparison Project (ACCMIP), Atmos. Chem. Phys., 13, 3063-3085, doi:10.5194/acp-13-3063-2013, 2013.

Thompson, A. M.: The oxidizing capacity of the Earth's atmosphere - probable past and future changes, Science, 256, 1157-1165, doi:10.1126/science.256.5060.1157, 1992.

Toumi, R., Haigh, J. D., and Law, K. S.: A tropospheric ozonelightning climate feedback. Geophys. Res. Lett., 23, 1037-1040, 1996.

Tsutsumi, Y., Makino, Y., and Jensen, J. B.: Vertical and latitudinal distributions of tropospheric ozone over the western Pacific: Case studies from the PACE aircraft missions, J. Geophys. Res., 108, doi:10.1029/2001JD001374, 2003

Voulgarakis, A., Naik, V., Lamarque, J.-F., Shindell, D. T., Young, P. J., Prather, M. J., Wild, O., Field, R. D., Bergmann, D., CameronSmith, P., Cionni, I., Collins, W. J., Dalsøren, S. B., Doherty, R. M., Eyring, V., Faluvegi, G., Folberth, G. A., Horowitz, L. W., Josse, B., MacKenzie, I. A., Nagashima, T., Plummer, D. 
A., Righi, M., Rumbold, S. T., Stevenson, D. S., Strode, S. A., Sudo, K., Szopa, S., and Zeng, G.: Analysis of present day and future $\mathrm{OH}$ and methane lifetime in the ACCMIP simulations, Atmos. Chem. Phys., 13, 2563-2587, doi:10.5194/acp-13-25632013, 2013.

Wang, C. and Prinn, G.: Impact of emissions, chemistry and climate on atmospheric carbon monoxide: 100-year predictions from a global chemistry-climate model, Chemosphere, 1, 73-81, 1999.

West, J. J., Szopa, S., and Hauglustaine, D. A.: Human mortality effects of future concentrations of tropospheric ozone, C. R. Geoscience, 339, 775-783, doi:10.1016/j.crte.2007.08.005, 2007.

Wild, O.: Modelling the global tropospheric ozone budget: exploring the variability in current models, Atmos. Chem. Phys., 7, 2643-2660, doi:10.5194/acp-7-2643-2007, 2007.

Wild, O., Fiore, A. M., Shindell, D. T., Doherty, R. M., Collins, W. J., Dentener, F. J., Schultz, M. G., Gong, S., MacKenzie, I. A., Zeng, G., Hess, P., Duncan, B. N., Bergmann, D. J., Szopa, S., Jonson, J. E., Keating, T. J., and Zuber, A.: Modelling future changes in surface ozone: a parameterized approach, Atmos. Chem. Phys., 12, 2037-2054, doi:10.5194/acp-12-20372012, 2012.

World Meteorological Organization: Scientific Assessment of Ozone Depletion: 2010, WMO Global Ozone Research and Monitoring Project - Report No. 52, Geneva, Switzerland, 2011.
Young, P. J., Archibald, A. T., Bowman, K. W., Lamarque, J.-F., Naik, V., Stevenson, D. S., Tilmes, S., Voulgarakis, A., Wild, O., Bergmann, D., Cameron-Smith, P., Cionni, I., Collins, W. J., Dalsøren, S. B., Doherty, R. M., Eyring, V., Faluvegi, G., Horowitz, L. W., Josse, B., Lee, Y. H., MacKenzie, I. A., Nagashima, T., Plummer, D. A., Righi, M., Rumbold, S. T., Skeie, R. B., Shindell, D. T., Strode, S. A., Sudo, K., Szopa, S., and Zeng, G.: Preindustrial to end 21 st century projections of tropospheric ozone from the Atmospheric Chemistry and Climate Model Intercomparison Project (ACCMIP), Atmos. Chem. Phys., 13, 2063 2090, doi:10.5194/acp-13-2063-2013, 2013.

Zeng, G., Morgenstern, O., Braesicke, P., and Pyle, J. A.: Impact of stratospheric ozone recovery on tropospheric ozone and its budget, Geophys. Res. Lett., 37, L09805, doi:10.1029/2010GL042812, 2010.

Zhang, H., Wu, S., Huang, Y., and Wang, Y.: Effects of stratospheric ozone recovery on photochemistry and ozone air quality in the troposphere, Atmos. Chem. Phys., 14, 4079-4086, doi:10.5194/acp-14-4079-2014, 2014.

Zhang, Y., Olsen, S. C., and Dubey, M. K.: WRF/Chem simulated springtime impact of rising Asian emissions on air quality over the U.S., Atmos. Environ., 44, 2799-2812, doi:10.1016/j.atmosenv.2010.05.003, 2010.

Zubov, V., Rozanov, E., and Schleisinger, M. E.: Hybrid scheme for three-dimensional advective transport, Mon. Weather Rev., 127, 1335-1346, 1999. 